\title{
El Castelo dos Mouros y la iglesia de São Pedro de Canaferrim en Sintra (Portugal). Un análisis desde la Arqueología de la Arquitectura
}

\section{The Castelo dos Mouros and the Church of S. Pedro de Canaferrim (Sintra, Portugal). An analysis from Archaeology of Architecture}

\author{
Marisa Barahona Oviedo ${ }^{1}$ \\ Dra. en Arqueología \\ José Ignacio Murillo Fragero² \\ Urbe pro Orbe Patrimonio Cultural, S. L. \\ Carlos Cauce Cañizares ${ }^{3}$ \\ Arqueólogo
}

\begin{abstract}
RESUMEN
El conjunto monumental Patrimonio de la Humanidad del Castelo dos Mouros de Sintra (Portugal) es un complejo arquitectónico formado por dos recintos amurallados, con una gran cisterna en el interior del mayor, y la pequeña iglesia de São Pedro de Canaferrim extramuros. Considerado "obra de moros" en la historiografía, y enmascarado en el siglo XIX bajo una restauración romántica que le dotó de aires de cuento, su análisis desde la Arqueología de la Arquitectura retrasa la construcción originaria del conjunto hasta la segunda mitad del siglo XII, en relación con la conquista cristiana de Lisboa.
\end{abstract}

Palabras clave: estratigrafía; técnica constructiva; mampostería; arquitectura medieval; románico; castillos; murallas; cisternas; siglos XII-XIII; siglo XIX.

\begin{abstract}
The monumental complex of the Castelo dos Mouros at Sintra (Portugal) is an architectural ensemble declared World Heritage Site. It is formed by two walled enclosures, with a large cistern inside the bigger one, and the small church of São Pedro de Canaferrim outside the walled enclosures. Thought to be "work of Moors" by historiography and hidden by a Romantic restoration in the $19^{\text {th }}$ century, the analysis of this site by means of the Archaeology of Architecture puts back the chronology of the castle and the church to the second half of the 12 th century, in relation to the Christian conquest of Lisbon.
\end{abstract}

Key words: stratigraphy; building technique; masonry; Medieval architecture; Romanesque; castles; walls; cisterns; $12^{\text {th }}$ and $13^{\text {th }}$ centuries; $19^{\text {th }}$ century.

Recibido: 02-04-2018. Aceptado: 06-10-2018. Publicado online: 04-07-2019

Cómo citar este artículo / Citation

Barahona Oviedo, M., Murillo Fragero, J. I. y Cauce Cañizares, C. 2019: "El Castelo dos Mouros y la iglesia de São Pedro de Canaferrim en Sintra (Portugal). Un análisis desde la arqueología de la arquitectura", Arqueología de la Arquitectura, 16: e080. https://doi.org/10.3989/arq. arqt. 2019.002

Copyright: (c) CSIC, 2019. (C) UPV/EHU Press, 2019. Este es un artículo de acceso abierto distribuido bajo los términos de la licencia de uso y distribución Creative Commons Reconocimiento 4.0 Internacional (CC BY 4.0).

\footnotetext{
barahonamarisa@gmail.com / ORCID iD: https://orcid.org/0000-0001-7706-6321

jimurillo@urbeproorbe.com / ORCID iD: https://orcid.org/0000-0003-2249-3224

carloscaucec@gmail.com / ORCID iD: https://orcid.org/0000-0003-2003-9001
} 
El Castelo dos Mouros, gracias a su situación sobre un promontorio de las estribaciones de la Sierra de Sintra, a la vista de la costa atlántica, domina una extensa planicie que se extiende hasta el estuario del río Tajo, permitiendo entender su función como centro de defensa de un territorio esencialmente rural (Coelho 2000: 210).

La fortificación dibuja un gran recinto de planta irregular en el que tradicionalmente se distinguen dos líneas de muralla (Figs. 1 y 2). La menor se sitúa en la zona más septentrional y alta de la fortificación y define un área explicada como alcazaba (Rodil y Carvalho 1995: 13; Coelho 2002: 391-392). El resto del recinto se interpreta como una gran albacara que daría abrigo a la población en momentos de conflicto (Pavón 1993: 20). Esta última hipótesis estaría avalada por la existencia de una gran cisterna subterránea en su perímetro (Coelho 2000: 210), importante referencia del castillo, que alimenta su leyenda por la abundancia de las aguas que recoge. Las descripciones y grabados de viajeros y estudiosos de los siglos XVIII y XIX califican la construcción de esta estructura hidráulica como "obra de moros", adscripción admitida por autores recientes (Coelho 2002: 391).

Extramuros del castillo y a escasos metros del lienzo este, se erige la pequeña iglesia de São Pedro de Canaferrim, de una nave y ábside rectangular. Interpretada como antigua mezquita en el imaginario romántico, hoy se acepta su cronología románica (Real 1982-1983; Saldanha 1988; Rodrigues 1995: 258; Cardim 1998: 221), descartando un posible origen visigodo (Serrão 1980).

La historiografía diferencia por su fábrica el tramo oriental de la muralla del castelo de los restantes de la fortaleza, lo que evidenciaría sucesivas reconstrucciones, atribuidas unas a la conquista cristiana, y otras a la intervención romántica del monarca Fernando II a mediados del siglo XIX (Campos 1965: 140-141; Pavón 1993: 2025; Coelho 2000: 210, 2002: 390-391). El estudio comparativo de esta primera fábrica con la de otros recintos

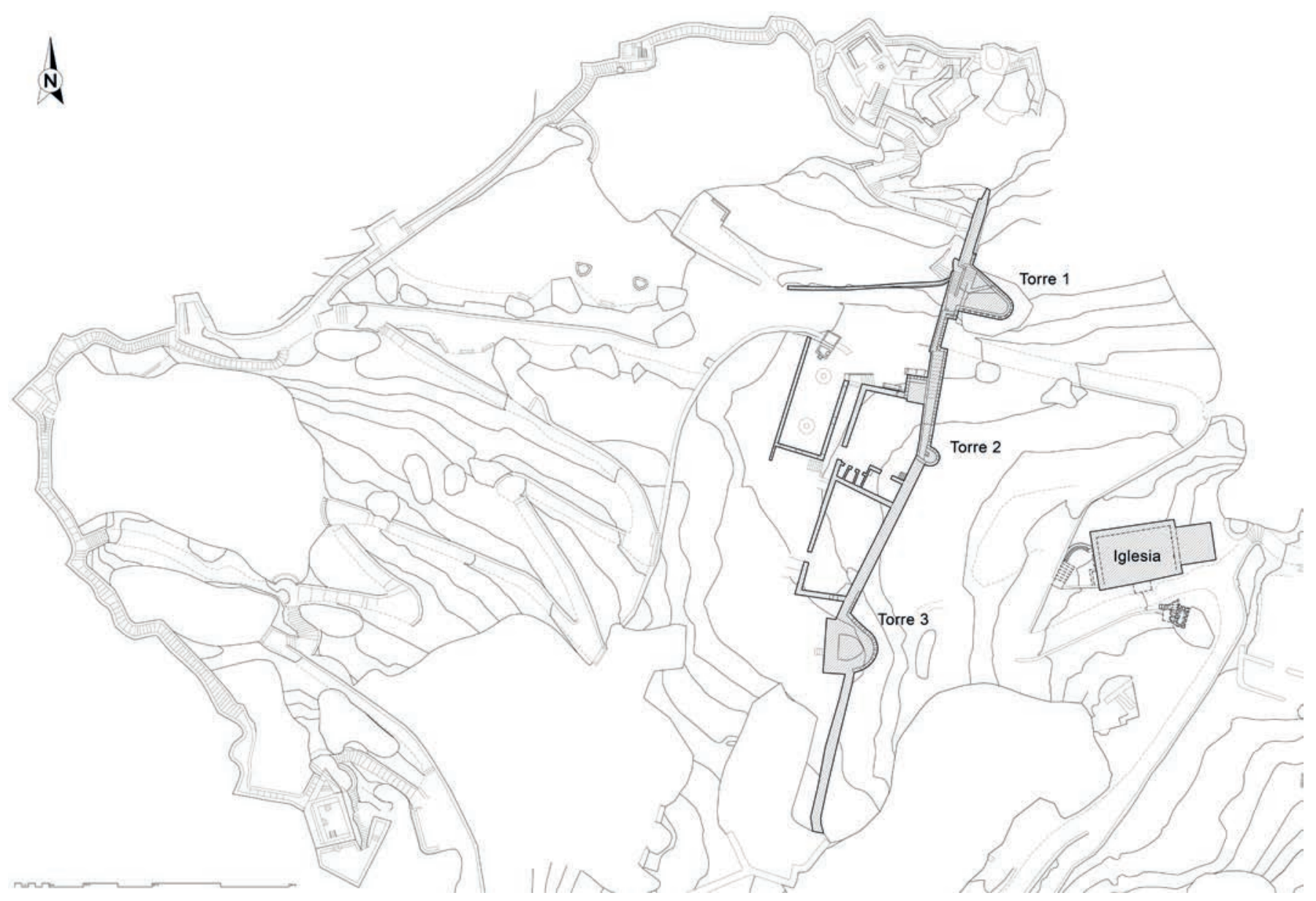

Figura 1. El conjunto del Castelo dos Mouros y estructuras analizadas (con trama). 


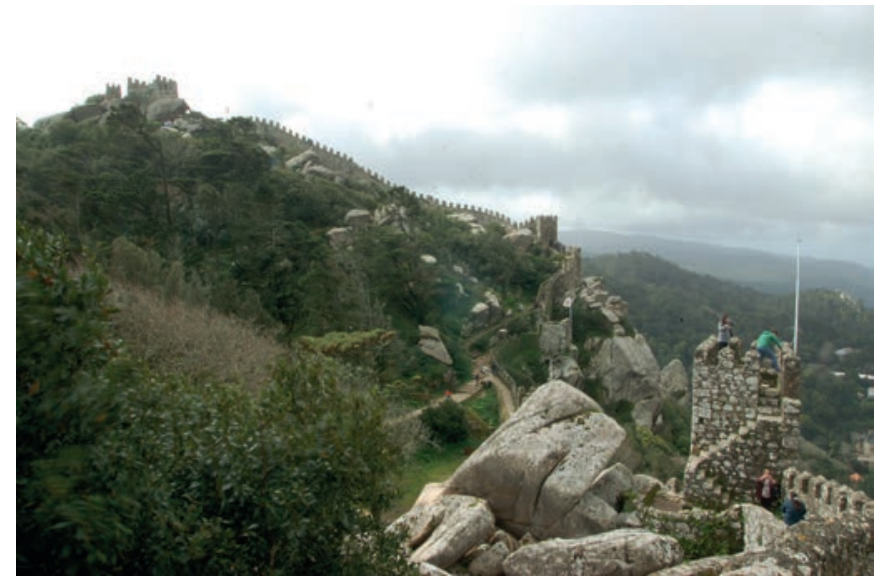

Figura 2. Vista general del recinto fortificado definido por la segunda línea de muralla.

amurallados peninsulares o del norte de África, considerados de época musulmana, llevó a Pavón (1993: 19-25) a concluir su construcción en los siglos IX-X, hipótesis admitida hasta el momento (Cardim 1998: 201; Coelho 2000: 210-214, 2002: 390-393). Si bien algunos autores preconizan una cronología de plena ocupación islámica para este lienzo (siglo XI), en atención a la mención de fortificaciones en Sintra en las fuentes de este periodo ${ }^{4}$, sin descartar tampoco un origen anterior para el mismo (Cardim 1998: 201; Torres y Macías 1995: 167).

También las excavaciones arqueológicas llevadas a cabo en la iglesia de São Pedro de Canaferrim, y en el espacio entre ésta y la muralla oriental del castelo, en los años 1981 y 1993-2001, evidenciaron un horizonte de ocupación islámica extramuros, de los siglos IX-XII, cuya cronología se hizo extensiva al conjunto de la fortificación. Más específicamente, y aunque los niveles de excavación se hallaron muy alterados por la intervención romántica del siglo XIX en el conjunto, fue posible distinguir unos primeros asentamientos poblacionales en el Neolítico Antiguo y Bronce Final.

\footnotetext{
${ }_{4}$ Sintra, Sintria o Cintra debió ser en época islámica un núcleo poblacional significativo, por su situación al Norte del estuario del Tajo, cercano al mar y próximo a los dos importantes polos urbanos de Lisboa y Santarem, en una región alabada en las fuentes islámicas de los siglos XII y XIII por la riqueza de sus recursos naturales. El escritor Al-Bakri (s. XI) la sitúa entre las ocho urbes más importantes del Garb al-Andalus, aunque no existe consenso en las fuentes sobre el estatus administrativo que ostentaría esta población (Coelho 2000: 208, 2002: 394). Tampoco sobre su localización exacta. El geógrafo Al-Idrisi (1099-1166) describe dos fortalezas en Sintra, identificada tradicionalmente una con el llamado Castelo dos Mouros (Pavón 1993: 20; Coelho 2002: 390), y siendo quizá la otra el antiguo palacio o residencia del gobernador musulmán en la villa, bajo el actual Palacio Real (Serrão 1989: 28). En este último lugar, los restos arqueológicos confirman un foco poblacional datable entre la IX y la XII centuria (Saldanha 1988: 35; Coelho 2002: 394). Se interpreta así la posible convivencia de un centro político en la sierra y una zona de medina y arrabal en la villa (Coelho 2002: 390).
}

Sobre ellos se superpone la ocupación de época islámica señalada, en la que fundamentalmente se documentan silos y espacios de almacenamiento. Finalmente, la necrópolis cristiana asociada a la iglesia de São Pedro de Canaferrim, que se extiende hasta el siglo XIV (Simões 1999: 31-73; Cardoso 1997-1998; Coelho 2000: 214218, 2002, 2012).

Las últimas campañas, realizadas entre los años 2009 y 2012, de nuevo junto al lienzo oriental de la fortificación, tanto al interior como al exterior del mismo, y en el marco de las cuales se llevó a cabo el presente estudio, ratificaron en líneas generales la secuencia histórica señalada: Neolítico Antiguo, Bronce Final, ocupación islámica entre los siglos IX-XII y necrópolis cristiana asociada a la iglesia, la cual se extiende incluso tras el lienzo de muralla (Sousa 2013, 2015; Cardoso y Sousa 2014; Sousa y Carvalho 2015; Fernandes et al. 2016; Gouveia y Sousa 2017). Sin embargo, algunas de las estructuras habitacionales islámicas documentadas en dichos trabajos aparecían amortizadas por la construcción de la muralla (Sousa 2015: 263), lo que supone la edificación de esta última con posterioridad a las mismas, a partir del siglo XII, planteando la necesidad de una revisión de la tradicional adscripción islámica del castillo.

\section{EL LIENZO ESTE DE LA MURALLA, LA CISTERNA ABOVEDADA Y LA IGLESIA DE SÃO PEDRO DE CANAFERRIM: ESTUDIO ARQUEOLÓGICO}

El análisis realizado, dentro del ámbito de la Arqueología de la Arquitectura, afecta al lienzo este de la muralla del segundo recinto del castelo, que cierra el acceso más fácil al mismo, en una vaguada de la montaña. También a la cisterna localizada en el interior de este perímetro, y a la iglesia extramuros de São Pedro de Canaferrim.

Los datos extraídos de la lectura de paramentos, la relación histórica de los elementos citados y las semejanzas tipológicas de sus fábricas, junto con los datos documentales y arqueológicos conocidos, permiten armar una evolución crono-constructiva del conjunto. Ésta retrasa la adscripcción cultural tradicionalmente considerada para el mismo, siendo posible definir siete etapas históricas que abarcan desde la segunda mitad del siglo XII hasta el siglo XX (Fig. 3).

El lienzo este de la muralla consta de 3 torres (que denominamos 1,2 y 3 , de Norte a Sur) y 4 paños de muralla, dos de ellos entre torres (paños $1 / 2$ y $2 / 3$ ) y los 


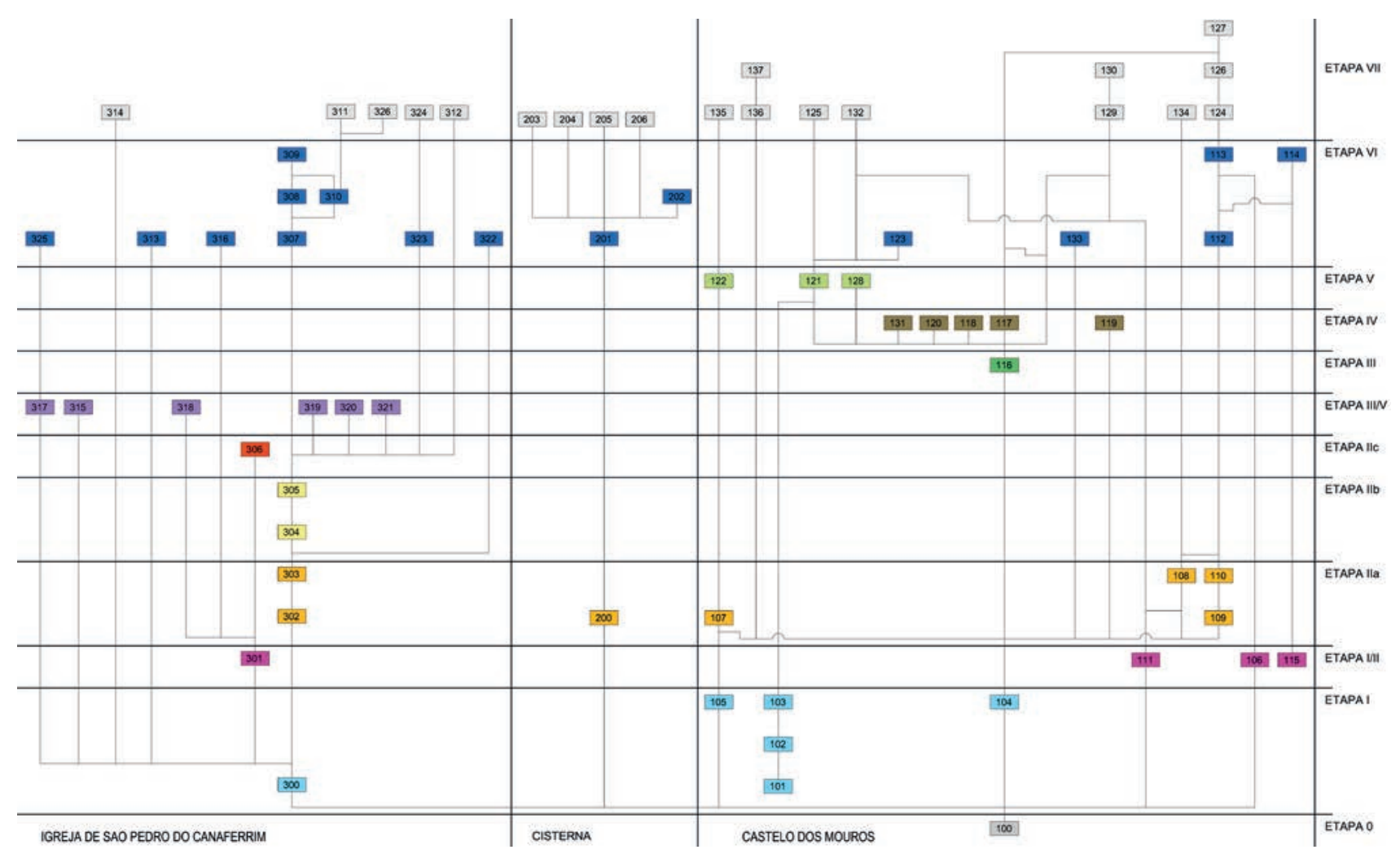

Figura 3. Castelo dos Mouros, cisterna e iglesia de S. Pedro de Canaferrim. Diagrama general de actividades.

otros dos, extremos, que se adosan contra la roca que aflora del terreno natural (paños $0 / 1$ y 3/4). En el extremo norte del paño $1 / 2$ se encuentra la puerta principal de la fortificación. Esta nomenclatura la hemos seguido tanto en el exterior como en el interior del lienzo de muralla.

Las habitaciones adosadas en el interior del recinto se denominan 1 y 2 (Norte y Sur respectivamente) y los muros que las conforman se identifican por su orientación cardinal.

La cisterna, de planta rectangular y cubierta abovedada, no presenta especiales problemas en su nomenclatura, siendo designados sus muros por su orientación cardinal, tanto al exterior como al interior.

El mismo sistema hemos seguido en la iglesia de San Pedro de Canaferrim, donde distinguimos además entre nave y cabecera.

\subsection{Etapa I (segunda mitad del s. XII - s. XIII). Construcción del castelo y la iglesia de Canaferrim}

[Muralla: A ${ }^{5}$ 101, UE 1202; A 102, UE 1201; A 103, UE 1200; A 104, UUEE 100110021004100710101016

\footnotetext{
5 A = Actividad (a partir de aquí en los epígrafes).
}

120312221223 1229; A 105, UE 1018; A 106, UE 1245; A 111, UE 1023; A 115, UE 1242. Iglesia: A 300, UUEE 16001614 1618]

La primera etapa identificada en el castillo supone la construcción de su línea defensiva oriental (AA 101, $102,103,104$ y 105), de la que desconocemos su cierre en el extremo norte, pero que define la fortificación originaria, incluyendo sus accesos. Su obra se conserva en todos sus paños (salvo el 0/1) y en dos de sus tres torres (salvo la 1), tanto en las caras externas como en las internas (Fig. 4).

Se trata de tres paños de muralla (paños $1 / 2,2 / 3$ y $3 / 4$ ), delimitados entre torres ( 2 y 3 ), cuyas características formales presentan notables diferencias. La torre 2, de pequeñas dimensiones, es maciza y su planta semicircular sobresale al exterior de la línea de muralla. La torre 3 es hueca y de mayor tamaño, sobresaliendo con planta semielíptica hacia el exterior de la fortificación y con una planta rectangular hacia el interior.

La fábrica de los lienzos y de las torres (UUEE $1002,1004,1007,1010,1129)$ es de mampostería de granito trabada con argamasa de cal, que se levanta por bancos de obra, conformando muros de doble hoja. Pese a la ausencia de mechinales, debieron 


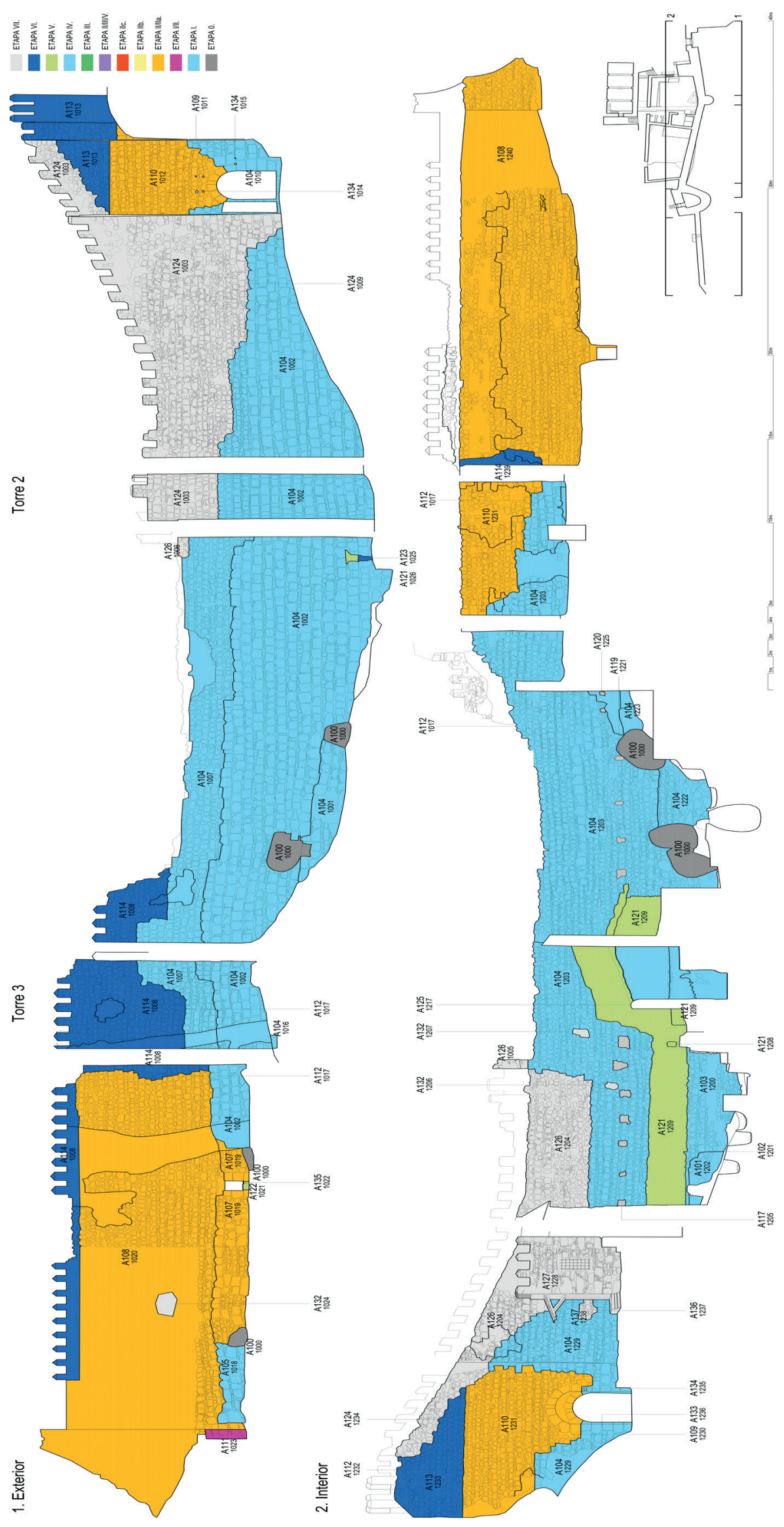


emplearse andamios para su edificación, dada la considerable altura de la muralla. Su aparejo es de sillarejos irregulares de gran tamaño y formas cuasi cuadrangulares, que se disponen en hiladas horizontales, alternándose con otras más pequeñas de regularización. Estas últimas quedaban ocultas tras un revoco de cal que sellaba las juntas, y que hoy sólo es visible en las zonas inferiores del muro, gracias a las excavaciones arqueológicas.

La obra fue construida directamente sobre el sustrato granítico del lugar, evidenciándose el empleo de zarpas de cimentación en algunos sectores (UUEE 1001, $1016,1200,1201,1202,1203,1222,1223,1229)$. Pese a las diferencias de aparejo observadas entre el interior y el exterior del lienzo (piezas más irregulares al interior), y de módulo, entre la parte inferior y la superior, las relaciones estratigráficas y sus características comunes (ausencia de mechinales de construcción y restos del revoco que sellaba las juntas), permiten considerarla una misma obra.

Las zarpas de cimentación de las torres 2 y 3 ya fueron observadas por Pavón, quien también remarcó las diferencias tipológicas y de módulo en la fábrica anteriormente señaladas (1993: 23), y que obedecen, en nuestra opinión, a criterios funcionales en el proceso constructivo. Factores "poliorcéticos" o estratégicos debieron influir, en cambio, en la diferente morfología señalada entre las torres 2 y 3 . La primera, un paso habitual del adarve, funcionaba estructuralmente a modo de contrafuerte, cosiendo los paños $1 / 2$ y $2 / 3$, excesivamente largos y situados donde el lienzo de muralla es más alto y se produce un ligero quiebro en su trazado. La torre 3, en cambio, actuaba como puesto de vigilancia avanzada y servía de acceso al adarve, con una escalera interior cuyos restos quedaron ocultos por la restauración romántica del siglo XIX (Etapa VI).

En definitiva, los constructores del castelo optaron por una manera rápida y económica de alzar muros de gran altura, espesor y longitud, regularizando con piezas menores, sillarejos elaborados solo parcialmente. Todo ello, junto con el rejuntado final de la obra, generaba un falso aspecto homogéneo y una imagen de solidez y buen hacer cuyo mérito consistió en maximizar el uso de la topografía como defensa natural (Figs. 5 y 6).

En la parte inferior norte de la torre 1 al exterior, y continua con la zona inferior del paño $0 / 1$, se identifican algunas hiladas de una fábrica de mampostería aristada con regularización (UE 1245). Aunque podría tratarse de la obra ya descrita de la Etapa I (UE 1002), puesto que hubo de existir un cierre topográfico del lienzo en el extremo septentrional, el módulo reducido de los mampuestos a una altura tan cercana a la cota de suelo podría equiparar esta fábrica con la posterior reforma de la puerta principal, en la etapa II (UE 1012).

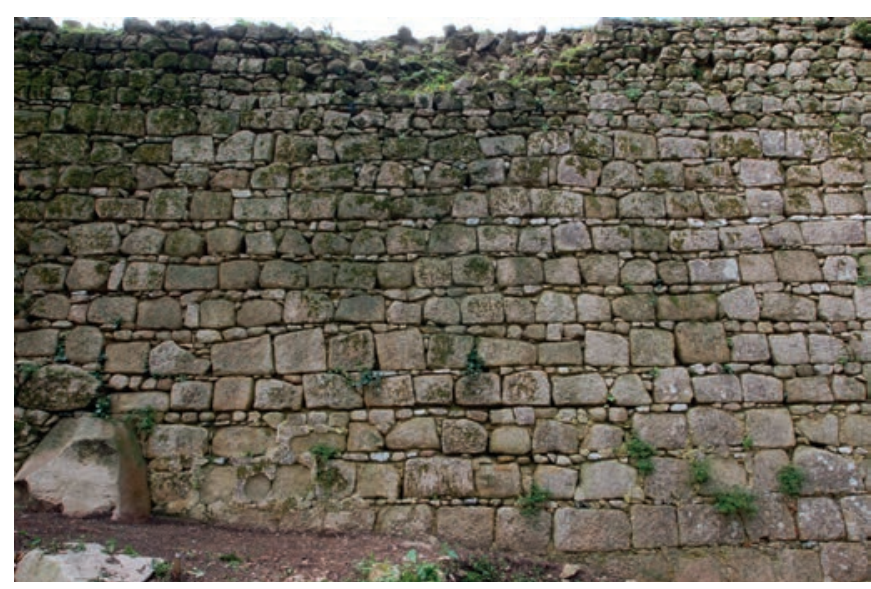

Figura 5. Paño 2/3 del lienzo oriental con restos del encintado de las juntas en la parte inferior.

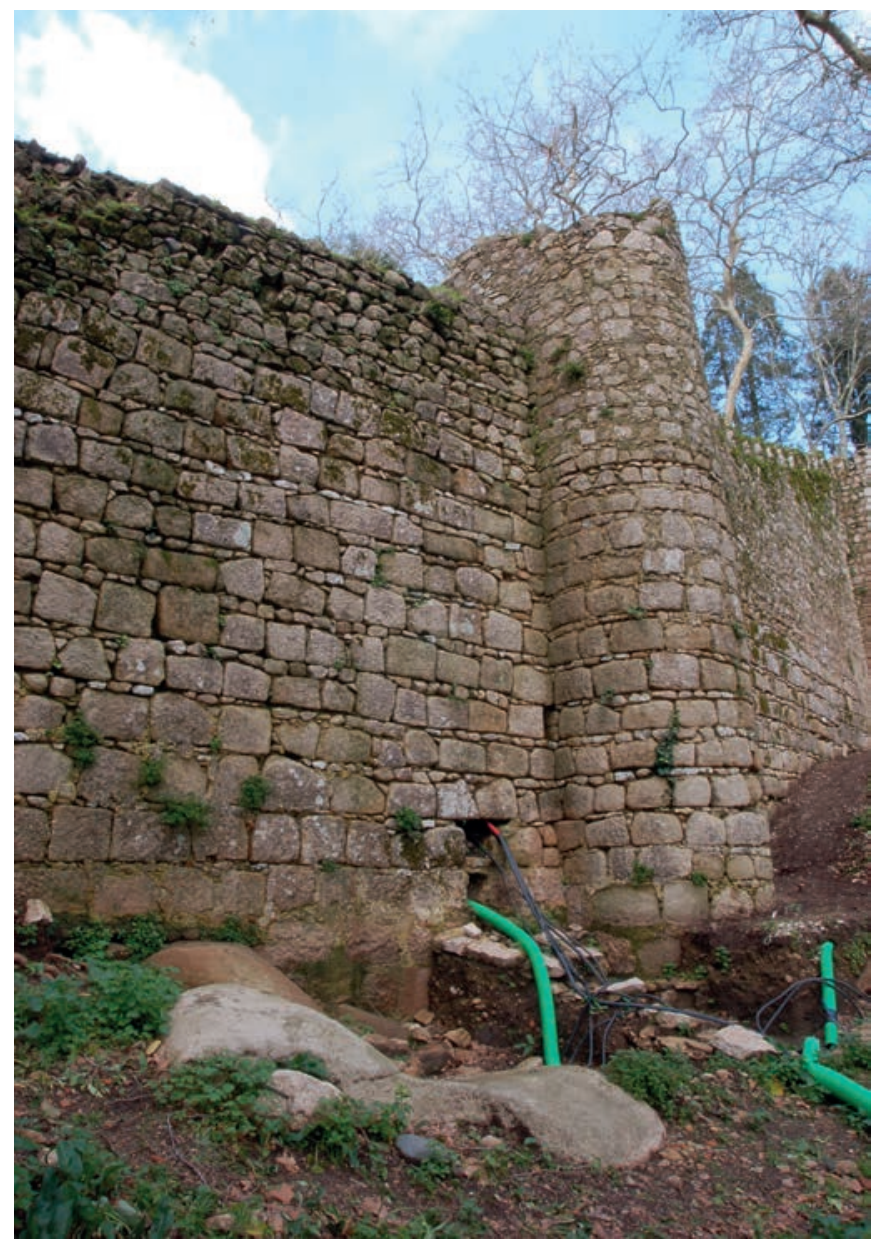

Figura 6. Entronque entre el paño $2 / 3$ y la torre 2 en el lienzo oriental, y agujeros de desagüe (Etapas VI y VII). 
En la parte inferior del paño 3/4 también queda aislada una unidad estratigráfica con restos de una jamba y un dintel (UE 1018). En este caso, por su identidad tipológica sí es posible equipararla con la obra originaria (UUEE 1002 y 1010), asegurando así que la primera muralla se extendía hasta dicho punto, en el extremo meridional del lienzo este, donde se abría un pequeño portillo.

La puerta de acceso principal al castillo se sitúa en el extremo contrario (paño $1 / 2$ ), que en su alzado exterior se remete en este punto respecto de la línea de muralla para proteger su acceso, flanqueado al norte por la torre 1 . Tanto al exterior como al interior de la puerta puede establecerse una clara diferencia entre las jambas, salmeres y fábricas laterales (UUEE 1010 ext. y 1129 int.), originarias, y las dovelas del arco y su fábrica (UUEE 1012 ext. y 1231 int.), pertenecientes a una etapa posterior (Etapa II). Los salmeres exteriores del arco, que se conservan en su posición original, trazan una figura de medio punto, negando la existencia previa de otro de herradura y proponiendo una cronología cristiana para la primera fase de la muralla, al menos en el lienzo estudiado (Fig. 7).

Estos datos son concordantes con los resultados de las últimas excavaciones realizadas en el lienzo este de la fortificación. Como se ha señalado, en ellas se constata la construcción de los paños de muralla $1 / 2$ y $2 / 3$ sobre estructuras habitacionales anteriores, asociadas a cerámicas domésticas encuadrables entre los siglos XI y XII, y que señalan una fecha post quem para la construcción de la muralla, a partir del siglo XII (Sousa 2015: 263).

En conclusión, los argumentos estratigráficos y tipológicos ofrecidos por el análisis de los alzados, así como los datos aportados por las excavaciones del subsuelo nos llevan a rechazar la cronología altomedieval de estos lienzos y, concretamente, su adscripción cultural islámica. Las fuentes documentales señalan la conquista cristiana de la ciudad de Lisboa en 1147 , lo que supuso la rendición pacífica de la población de Sintra, a la que otorgó fuero de villa el monarca Alfonso Henriques en 1154 (Serrão 1980; Cardim 1998: 26-27; Coelho 2002: 394). De esta manera, se puede inferir la construcción del castillo a partir de la segunda mitad del siglo XII, igualándolo cronológicamente con la iglesia extramuros de São Pedro de Canaferrim, de época románica como ya se ha indicado (Real 1982-1983; Saldanha 1988; Rodrigues 1995: 258; Cardim 1998: 221), y con la que guarda semejanzas tipológicas como se verá a continuación.

Al igual que el castelo, la obra de la iglesia de Canaferrim es de mampostería de granito, aunque emplea piezas más heterogéneas, que se disponen en hiladas horizontales continuas. La fábrica se levanta de nuevo con muros de doble hoja, por medio de bancos, pero emplea para su edificación andamios con agujas pasantes (UUEE 1600, 1614 y 1618), a diferencia de la obra del castelo. Como en la fortificación, también se observan diferencias de módulo entre los mampuestos de la nave (UUEE 1614 y 1618) y los sillarejos del testero del ábside (UE 1600), que una vez más se deben relacionar con un cuidado en la cimentación de éste último. Otra peculiaridad de la cabecera, de nuevo vinculable con la obra del castillo, es el rejuntado de sus muros, conservado aún en algunos puntos (Fig. 8).

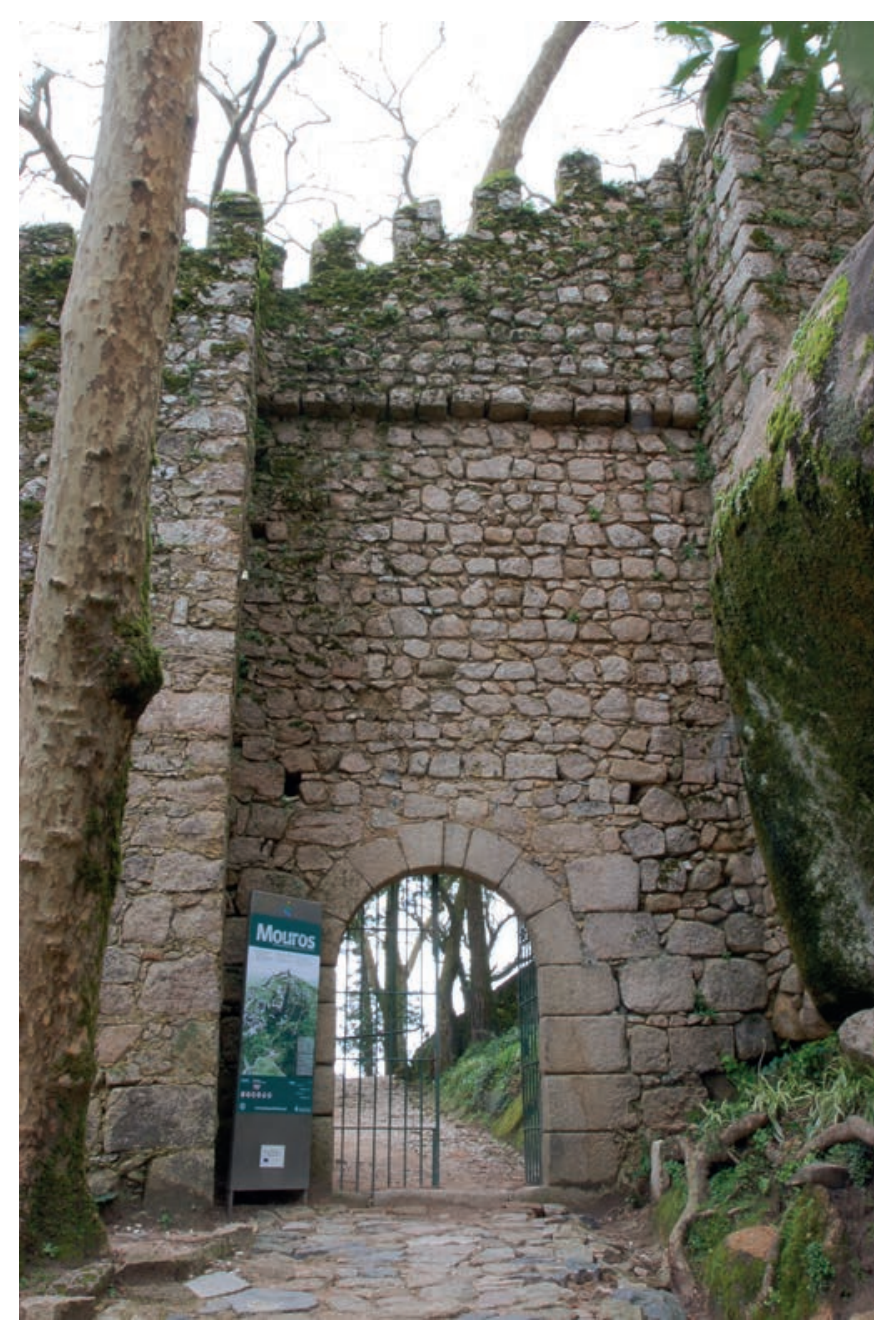

Figura 7. Puerta de acceso al castelo en el lienzo oriental, al exterior. 


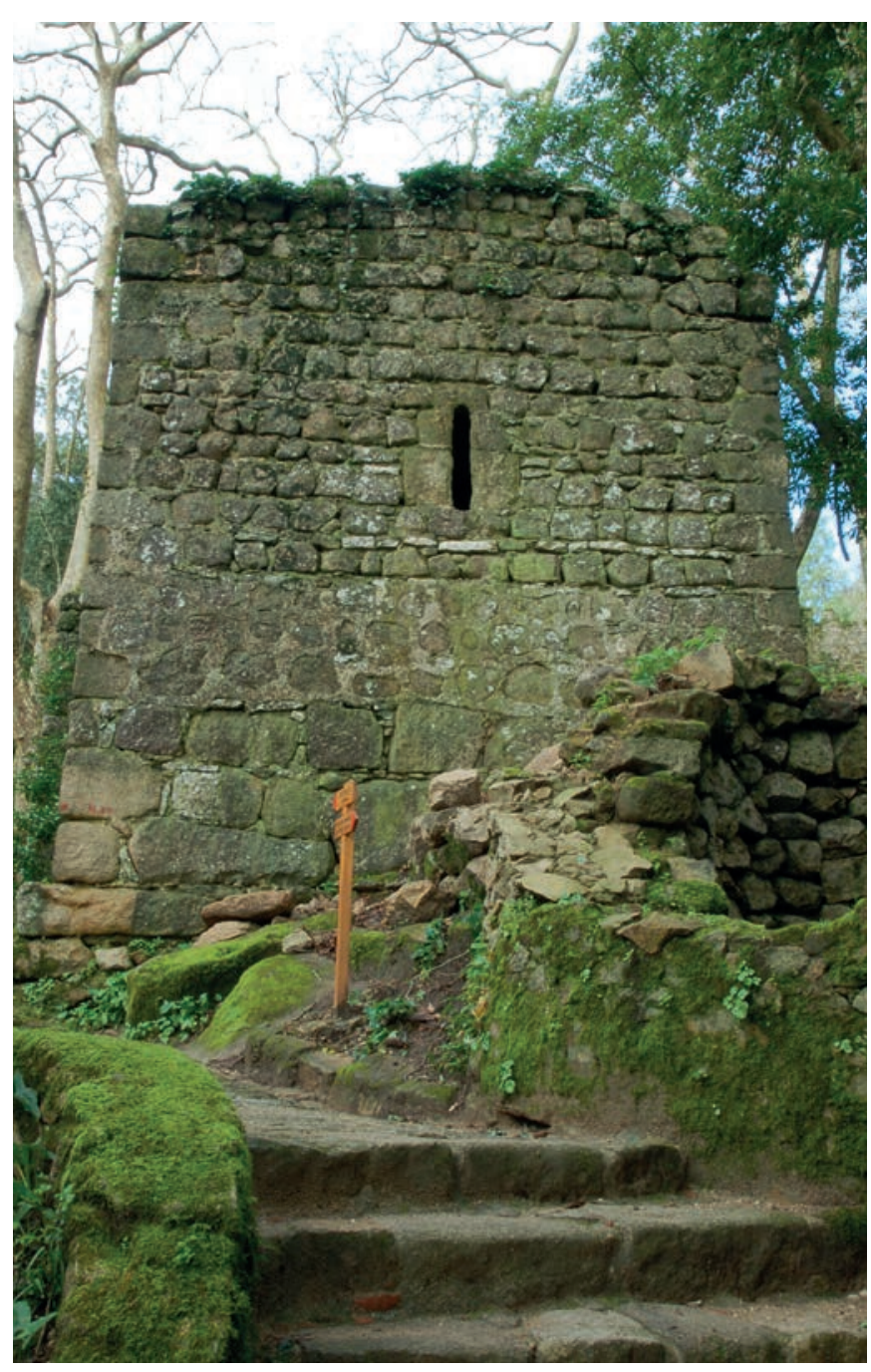

Figura 8. Testero del ábside de la iglesia de S. Pedro de Canaferrim.

En el ábside, pertenecen al momento originario su cubierta abovedada, la estrecha ventana de su testero, las dos credencias de los muros norte y sur (a las que se ha asignado una cronología moderna que debe rechazarse; Serrão 1980) y el arco de su embocadura, con sus jambas, impostas, arco doble y columnas entregas con basas y capiteles decorados. El acceso sur de la iglesia conserva su morfología original de arco de medio punto con tímpano, a pesar de su restauración en el siglo XX (Etapa VII; Fig. 9); mientras que las ruinas sucesivas del acceso oeste impiden conocer su tipología primitiva.

El estudio de los capiteles del ábside y de la portada sur marca un horizonte de construcción de la iglesia dentro del románico avanzado, entre la segunda mitad del siglo XII y principios del XIII (Figs. 10 y 11). Por

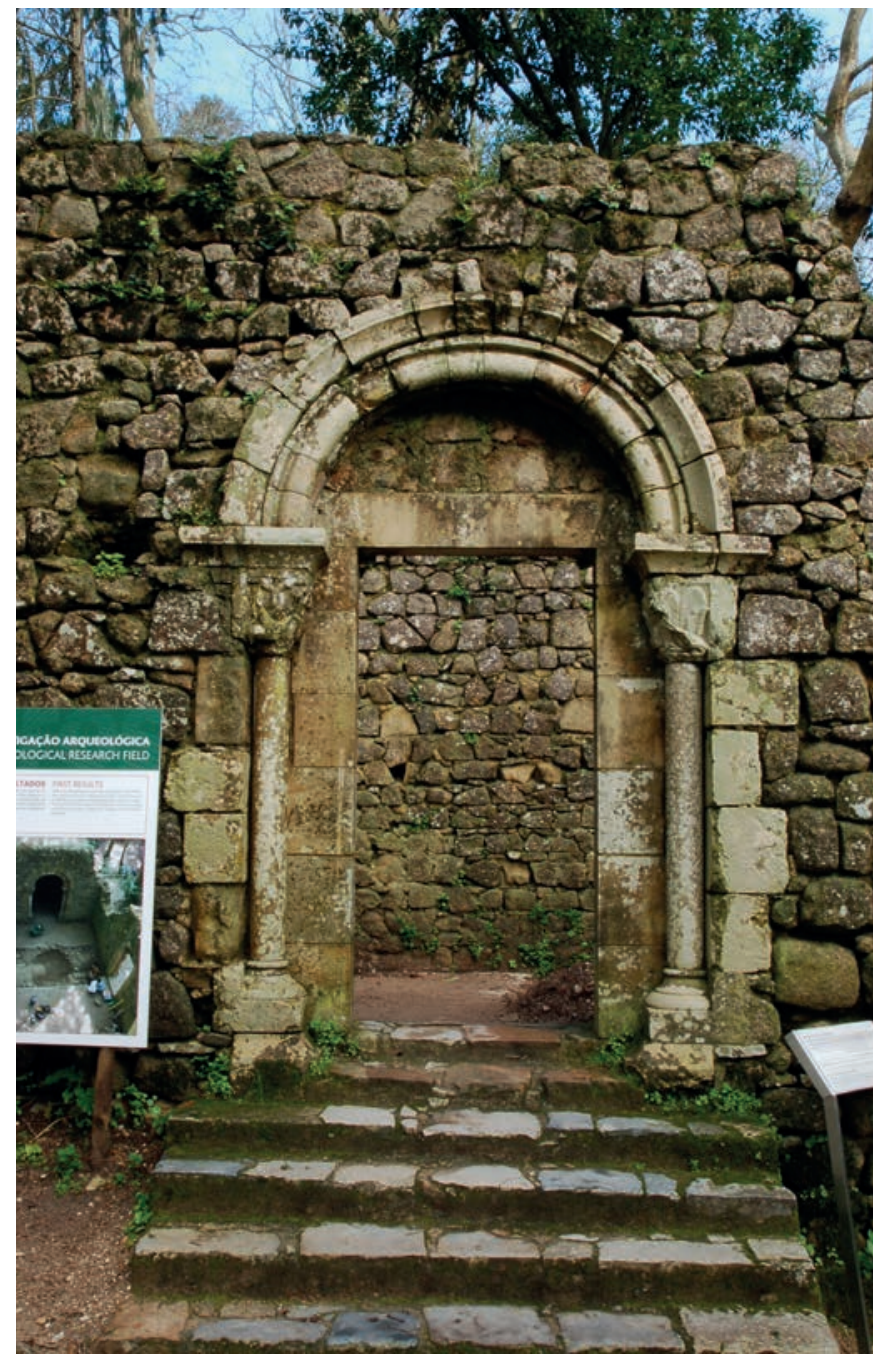

Figura 9. Portal sur de la iglesia restaurado (Etapa VII).

tanto, hemos de remitirnos nuevamente a la conquista cristiana del territorio en 1147 y a la concesión de Carta Fuero en 1154 por parte del monarca Alfonso Henriquez a la villa de Sintra. Por este documento, su concejo quedó dividido en cuatro demarcaciones parroquiales: San Pedro, San Martinho, Santa María y San Miguel, identificándose la de San Pedro de Canaferrim con la presente capilla, según las fuentes la mayor de todas las de Sintra (Costa 1980: 60-67; Serrão 1980; Real 1982-1983: 557-558; Saldanha 1988: 36; Cardim 1998: 27; Simões 1999: 32). Estas cuatro parroquias fueron en origen, por tanto, de patronato regio. Sin embargo, la iglesia de San Pedro fue posteriormente cedida al obispo de Lisboa, en el año 1245 , bajo el reinado del monarca Sancho II (1223-1248) (Serrão 1980; Saldanha 1988: 36; Cardim 1998: 27). 


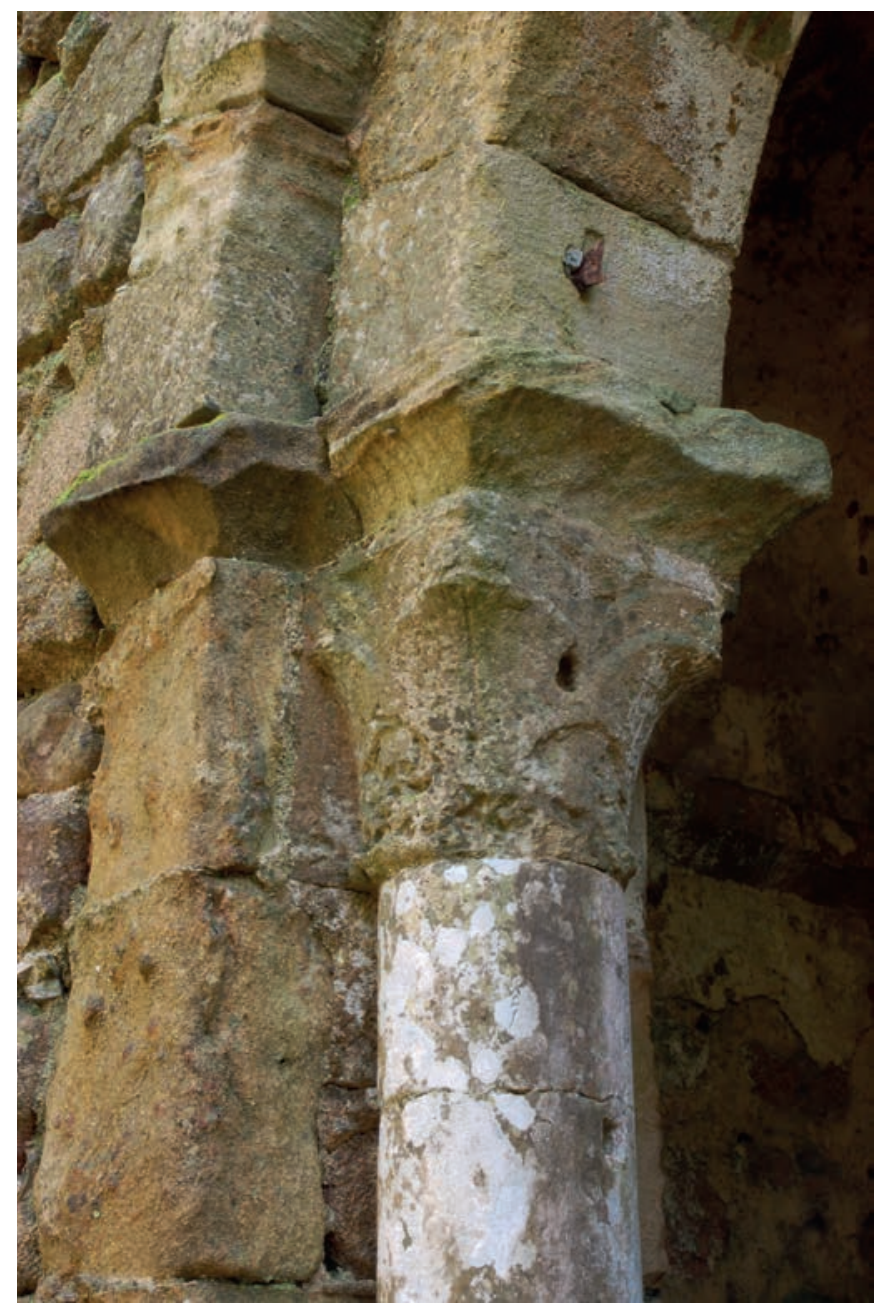

Figura 10. Arco de embocadura del ábside de la iglesia. Capitel norte.

\subsection{Etapa II (siglos XIII-XIV). Ruinas estructurales y reformas históricas}

[Muralla: A 107, UE 1109; A 108, UUEE 1020 1240; A 109, UUEE 1011 1230; A 110, UUEE 1012 1231. Iglesia: (Etapa IIA) A 302, UE 1628; A 303, UE 1619; (Etapa IIB) A 304, UUEE 16201623 1624; A 305, UUEE 1601 1621; (Etapa IIC) A 306, UE 1605. Cisterna: A 200, UE 1500]

En el lienzo este del castillo se constatan dos derrumbes y restauraciones, independientes entre sí, en el paño 3/4 (AA 107 y 108) y en el acceso principal (AA 109 y 110$)$.

En la reconstrucción del paño $3 / 4$ se emplea un aparejo en la base al exterior, que combina cajones de mampostería entre machones de sillería (UE 1019), sobre el que se alza una fábrica de

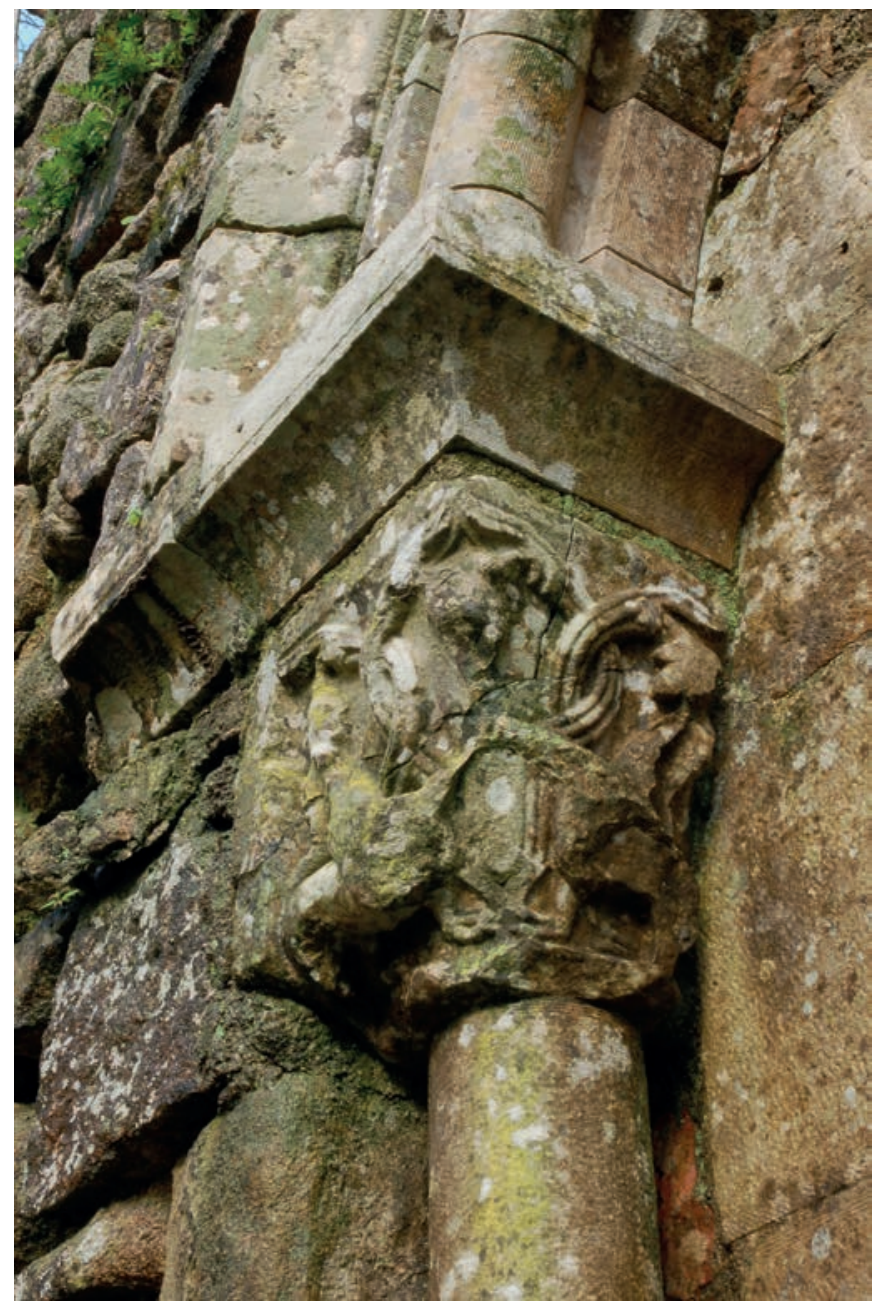

Figura 11. Portal sur de la iglesia. Capitel oeste.

mampostería ordenada, con hiladas de regularización y sin mechinales de construcción, que se eleva por bancos de obra (UUEE 1020 ext. Y 1240 int.). En su edificación se amortizó el portillo del extremo sur (Fig. 12), que fue sustituido por otro nuevo en el extremo opuesto con dintel en "T" y jambas de sillería con derrame interior, indicando el uso habitual de dicho paso (Fig. 13).

El derrumbe del acceso principal (UUEE 1230 y 1011) obligó a rehacer su arco desde las jambas, al interior, y desde los salmeres, al exterior (UUEE 1231 int. y 1012 ext.). Destaca en esta restauración el quicio de la jamba sur, realizado ex profeso para esta obra como demuestran su material y talla diferente (caliza blanca y "gradina"), además de estar acuñada, lo que aporta una cronología de la segunda mitad del s. XII (Bessac 1986: 67, "gradina"). Estos datos permiten situar la restauración de este vano en 


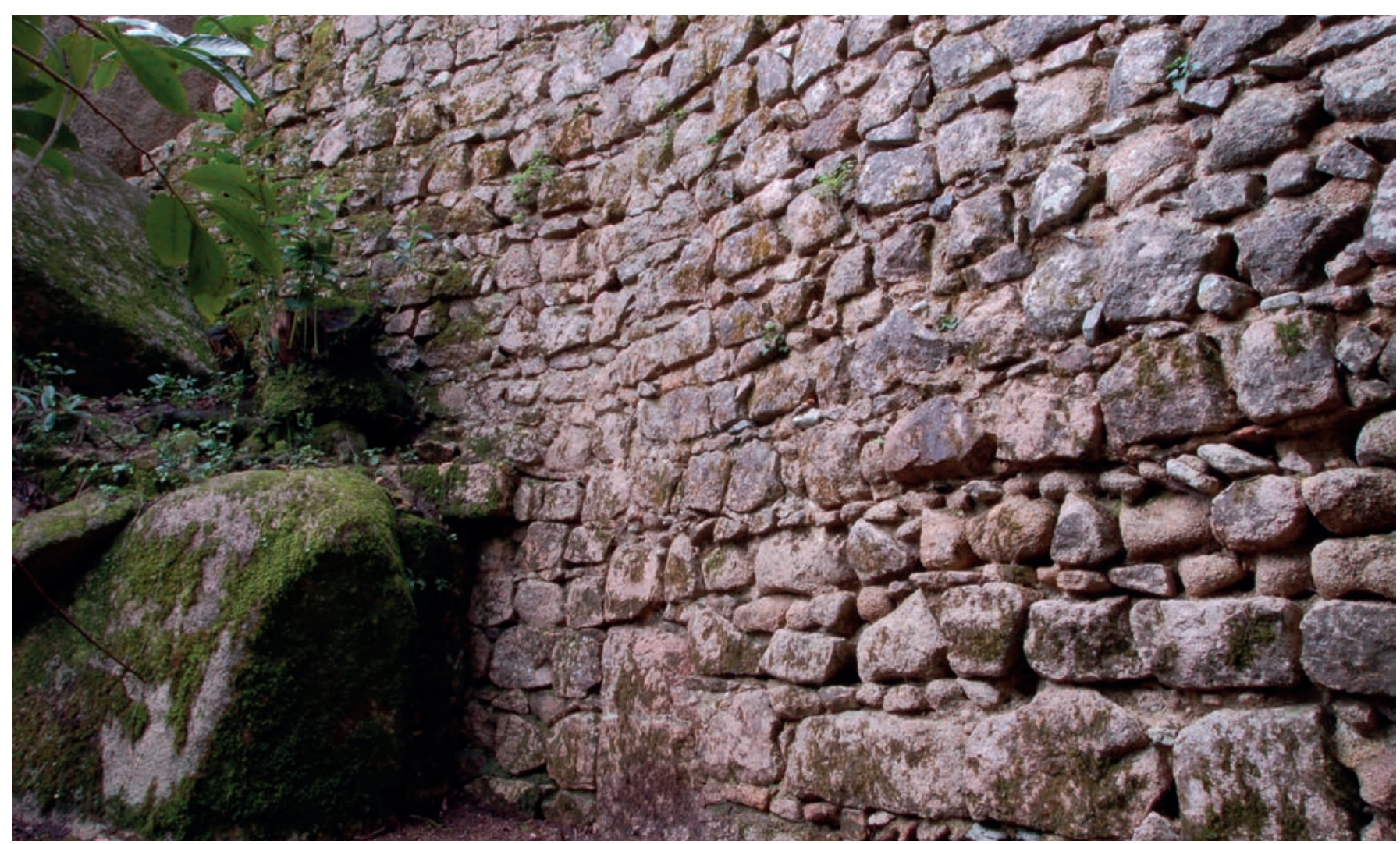

Figura 12. Lienzo oriental. Posible portillo con dintel de piedra en el extremo meridional del paño 3/4.

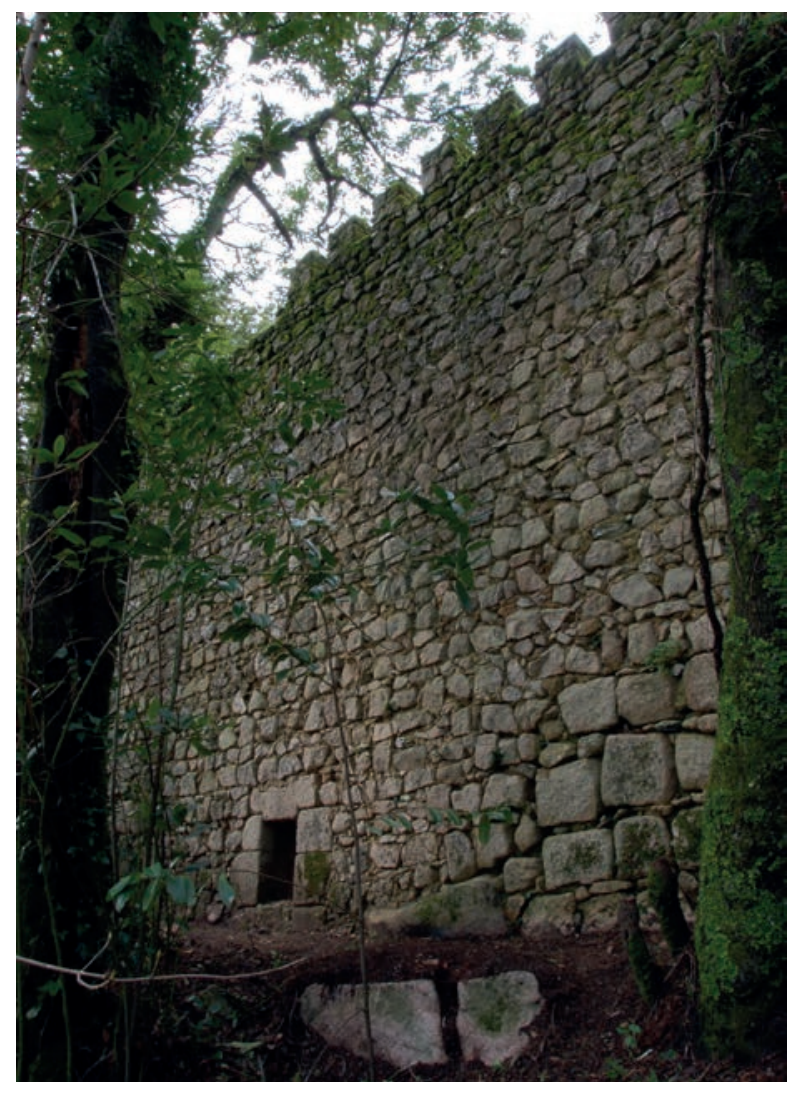

Figura 13. Lienzo oriental. Paño 3/4 reconstruido y portillo (Etapa II). época plenomedieval o en la Baja Edad Media (Figs. 14 y 15$)$.

Esta reforma incluyó también la reconstrucción del paño sobre la puerta, con un aparejo cuidado y regular, alzado con andamios armados con almas. También la construcción o la restauración de la parte inferior de la torre 1 y del paño 0/1 (UE 1245) ${ }^{6}$. Y es que, dado que estos últimos elementos no se conocen con seguridad en la etapa primera, puede proponerse que la reparación de la puerta de acceso al castillo supusiera, o bien la reconstrucción de estas fábricas tras su hipotética ruina (lo más probable, caso de aceptar su existencia en la primera etapa), o bien su construcción ex novo.

Podemos concluir que la ruina y la reconstrucción de la puerta se producirían en momentos seguidos, encuadrables en la Plena o en la Baja Edad Media y que, aunque no podemos relacionar esta reconstrucción con la del paño $3 / 4$, ambas obras afectaron a largos tramos del lienzo este, lo que supone un uso habitual de la fortificación que justifique tal inversión. Distintos documentos mencionan reconstrucciones en la fortaleza por

\footnotetext{
6 Como ya se ha señalado, no es posible aseverar sobre si los restos de la fábrica UE 1245 pertenecen a la etapa I o a la II.
} 


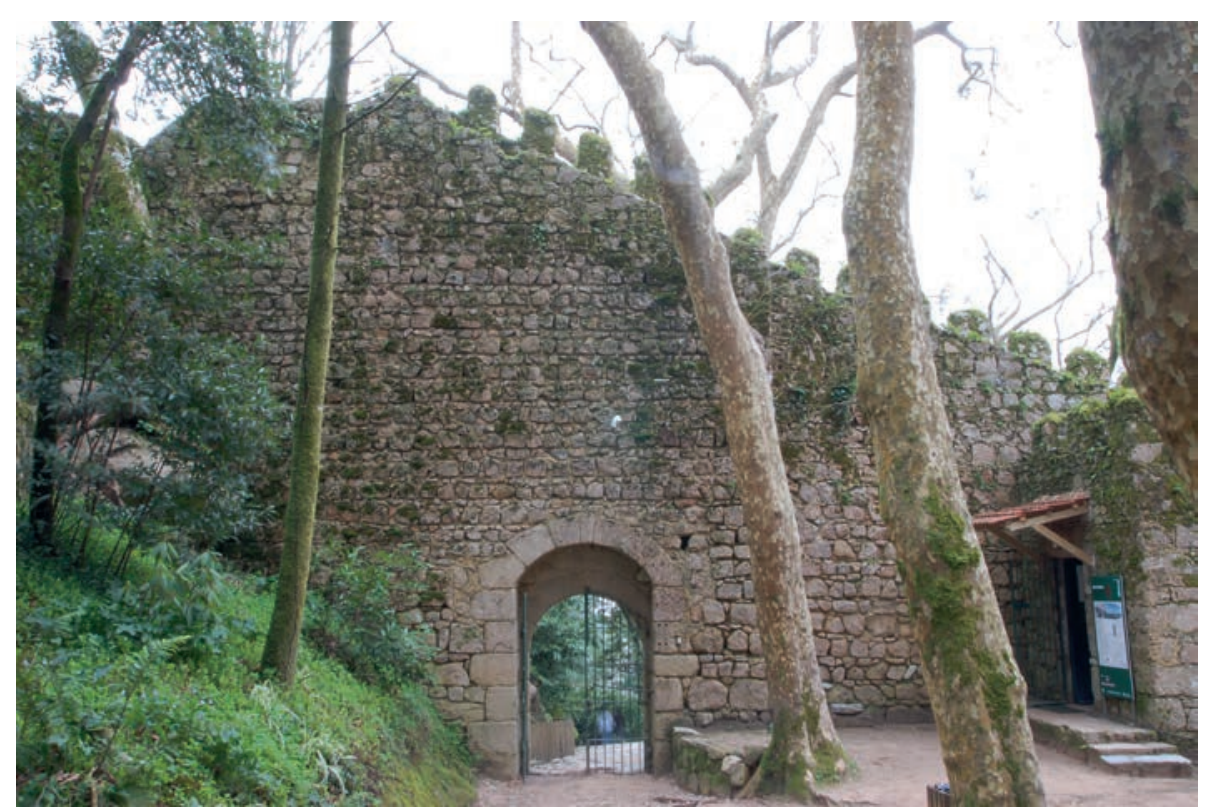

Figura 14. Reconstrucción histórica (Etapa II) del arco de la puerta del lienzo oriental (interior).

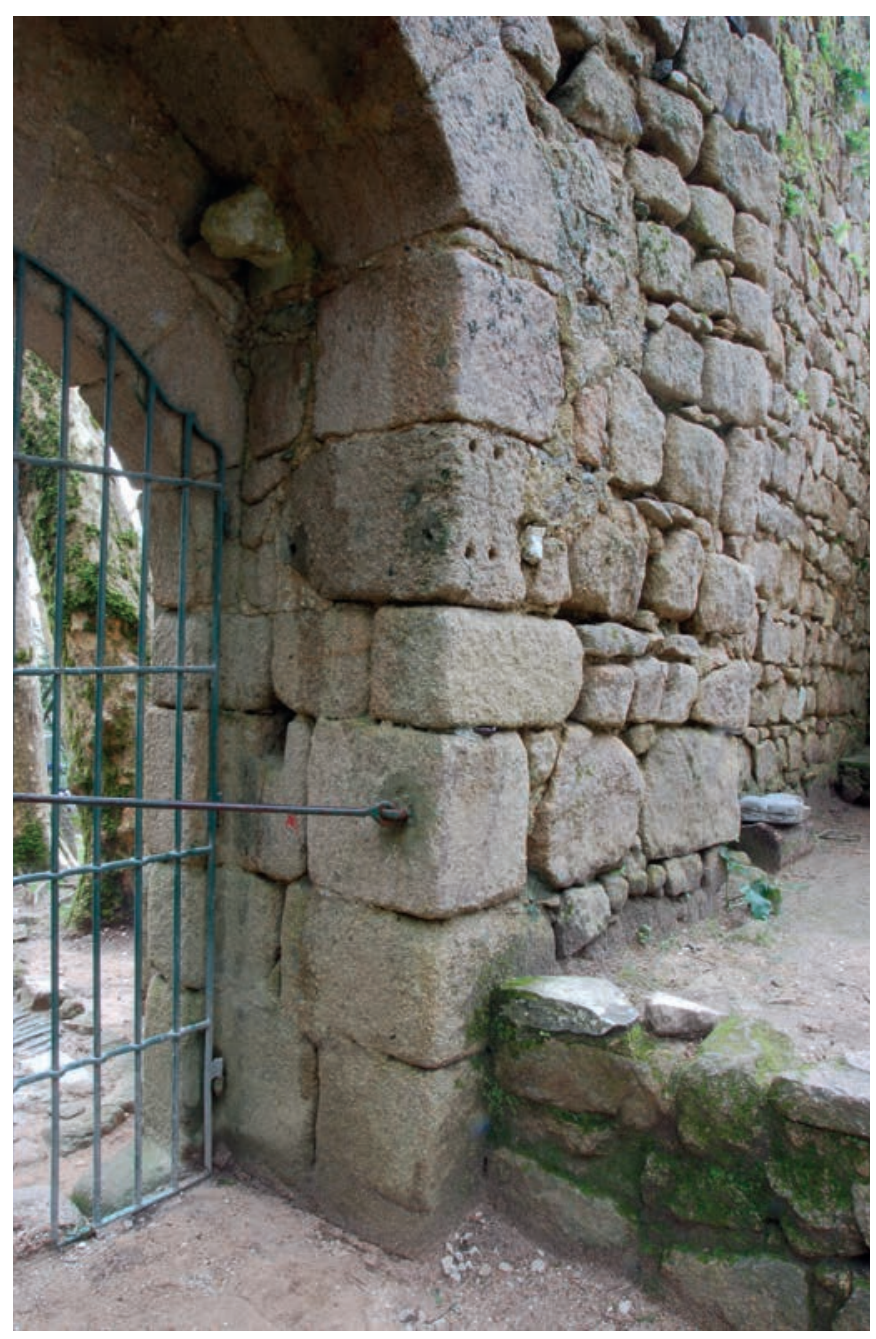

Figura 15. Jamba sur de la puerta principal del castelo al interior, con gorronera de material y talla diferente. el monarca Alfonso Enriques en 1149 y durante los reinados de Sancho I "el Poblador" (1154-1212) y de Fernando I "el Hermoso" (1373). También señalan un último alcaide de la fortaleza a finales del siglo XIV (1383; Castro 1843: 8-9 y Coelho 2002: 391), debiendo ésta quedar despoblada a finales de la centuria, lo que parece constatarse en las excavaciones arqueológicas llevadas a cabo en el entorno del lienzo este del castillo (Simões 1999: 41-45; Sousa 2013; Gouveia y Sousa 2017). No obstante, existen también referencias del asentamiento de una comunidad judía en el castelo, durante el siglo $\mathrm{XV}$, segregada del resto de la población por orden regia y expulsada definitivamente por el monarca D. Manuel I en 1496 (Cardim 1998: 220).

En la iglesia de São Pedro de Canaferrim se documentan asimismo reformas sucesivas, encuadrables en la etapa II (Fig. 16). La primera de ellas (IIA) se produjo tras la ruina, probablemente temprana, del muro norte de la nave y de la parte septentrional del testero oeste (UE 1628). Su reconstrucción (UE 1619) se efectúa con una fábrica de mampostería heterogénea, levantada por bancos de obra con mechinales pasantes, donde la unión de la esquina noroeste de la nave se refuerza con encadenado de sillería al exterior. La reforma supuso la construcción o reconstrucción de un vano rectangular en el muro norte, cuya diferencia de cota con el nivel de la iglesia es importante (más de $1 \mathrm{~m}$ ), lo que plantea el problema de su función, ya que es difícil conciliar el uso simultáneo de tres puertas para la pequeña capilla (accesos sur, oeste y norte). Saldanha (1988: 37), siguiendo 

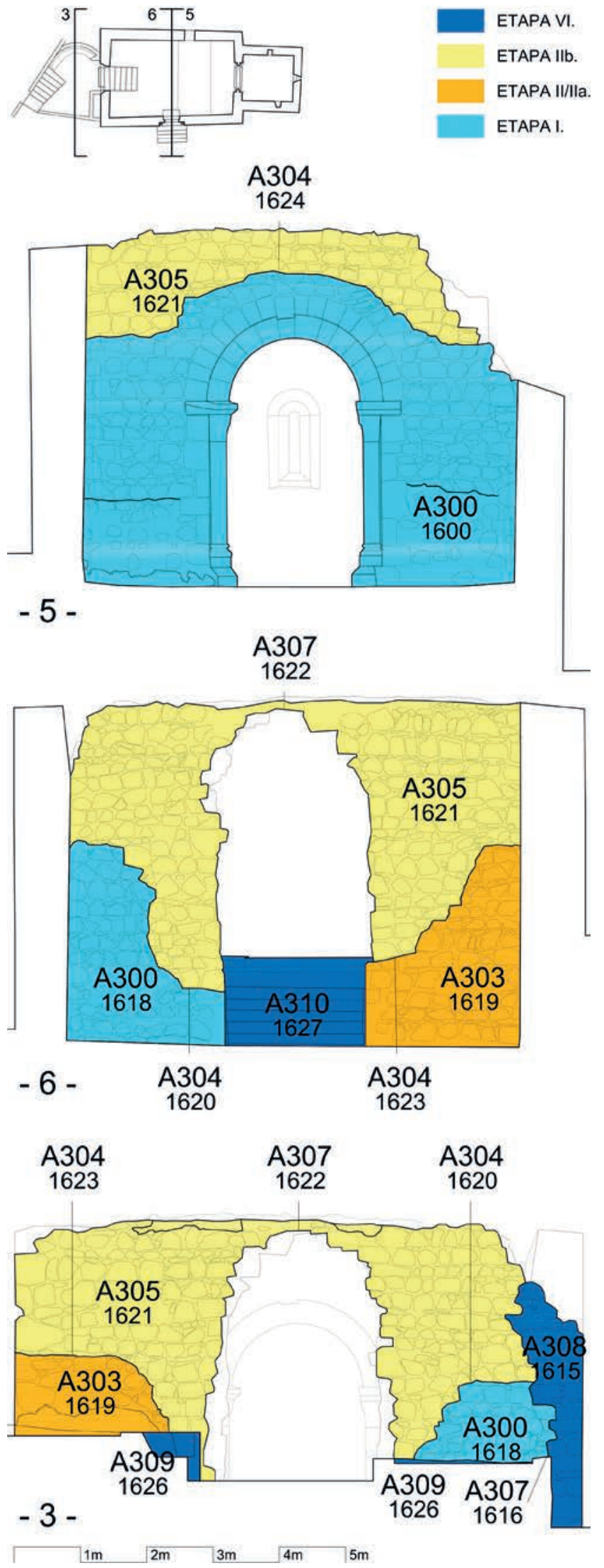

Figura 16. Iglesia de S. Pedro de Canaferrim. Secciones transversales con lectura estratigráfica. otros ejemplos portugueses, supone la existencia de una sacristía, torre u otra estancia aneja al muro norte, que no habría llegado hasta nosotros por estar realizada con materiales perecederos (Fig. 17).

Tras esta reforma, de nuevo fallaron los muros norte y oeste (A 304), implicando otra reconstrucción (IIB, UUEE 1601 y 1621), también en mampostería, que se dispone en hiladas sinuosas con piezas escuadradas, algo mayores que en la reforma anterior (Fig. 18). Esta segunda ruina afectó de nuevo al vano norte, con un dintel posiblemente más alto que el originario, y sobre el que se abren además tres pequeñas ventanas adinteladas, estrechas y abocinadas. También supone la presencia de una puerta en el muro oeste, donde sendas impostas en este acceso evidencian la existencia de un arco, cuya sillería fue robada posteriormente (Fig. 19). De nuevo se plantea un problema de interpretación por si hubo o no un vano previo y la diferencia de cota con el suelo de la nave. Si, como

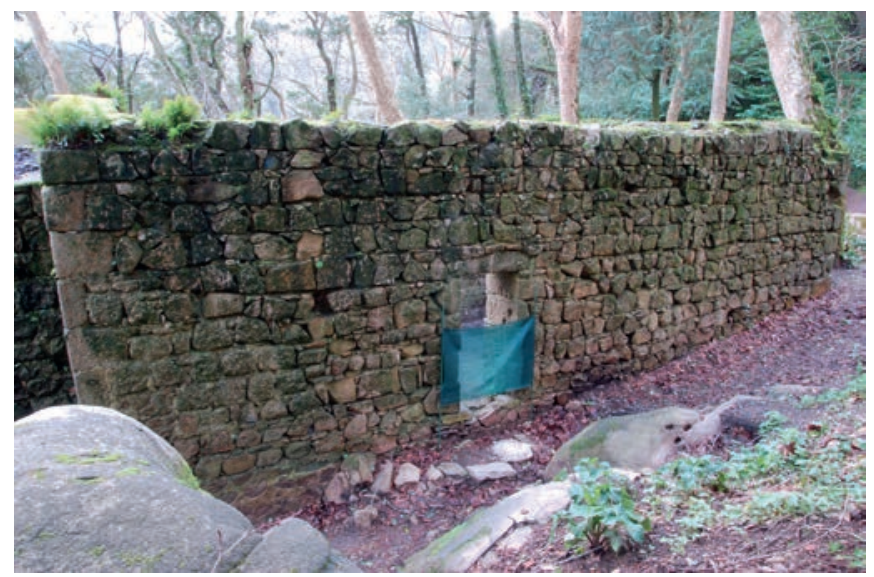

Figura 17. Alzado exterior del muro norte de la iglesia de S. Pedro de Canaferrim.

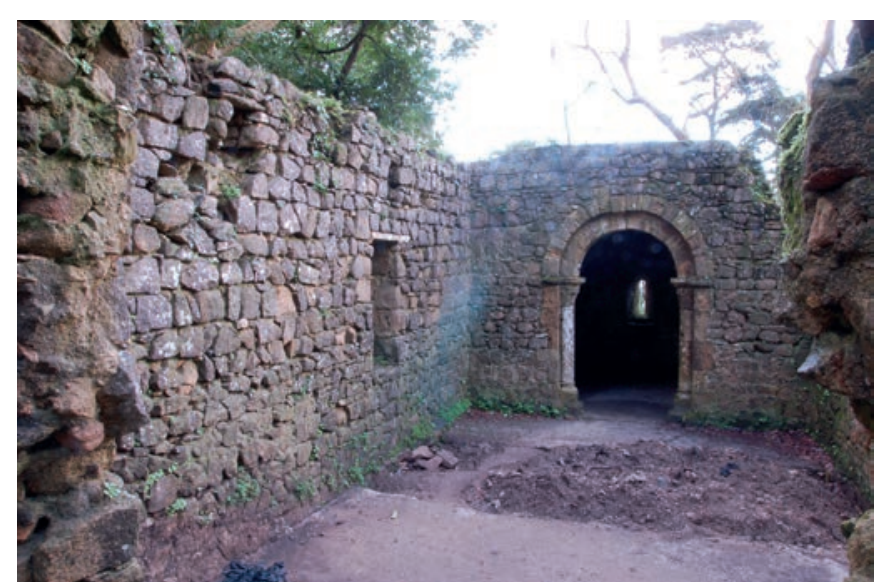

Figura 18. Interior de la iglesia de S. Pedro de Canaferrim. 


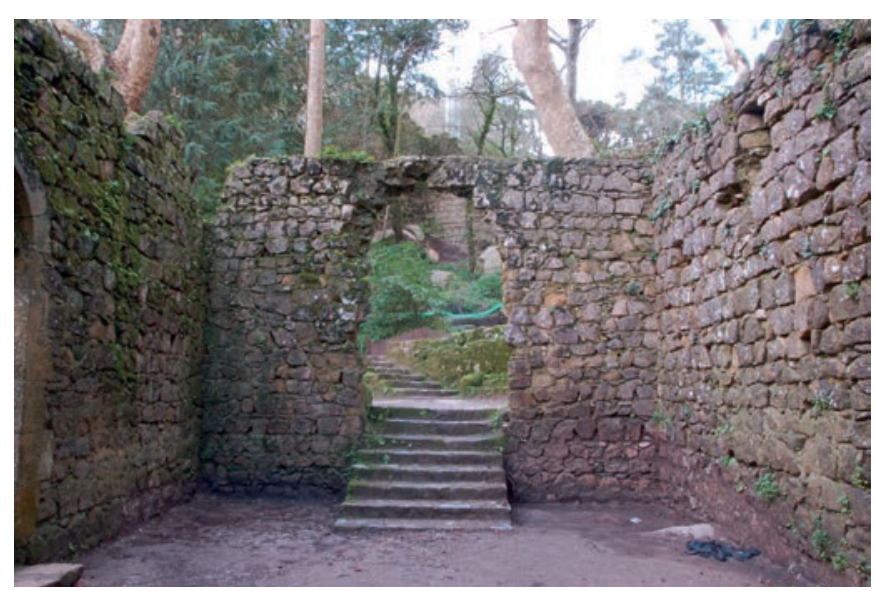

Figura 19. Acceso oeste al interior de la nave de la iglesia de S. Pedro de Canaferrim.

afirma Real (1982-1983: 529-560), los capiteles existentes en el Museo Arqueológico de Sintra pertenecieron a esta portada oeste de la capilla, debemos aceptar su existencia desde la primera etapa, puesto que estos capiteles y los del arco del ábside son coetáneos, en opinión de este autor ( $I b .531$ y 537). Lamentablemente, carecemos de otros argumentos que vinculen estas piezas del museo con la iglesia de Canaferrim.

La última reforma (IIC) corresponde a la decoración pictórica del ábside, de la que aún quedan restos (UE 1605). La posición estratigráfica de estas pinturas, posteriores al rejuntado original y al encalado interior ${ }^{7}$, preconiza una cronología tardía para las mismas. Su datación en época gótica (siglo XV) (Serrão 1980) ratifica su alejamiento de la obra románica, indicando además la prolongación del uso cultual de este espacio ${ }^{8}$ (Fig. 20).

Un documento de 1493 recoge el abandono del edificio en esta fecha, señalando su profanación por la comunidad judía segregada en la fortaleza (Cardim 1998: 222). La gradual transferencia política y poblacional del núcleo habitacional en altura a la villa en crecimiento al pie de la sierra, y la remodelación de la iglesia de San Pedro de Penaferrim en el siglo XVI, nombrada sede parroquial frente a la antigua de la fortaleza, debieron ser factores decisivos en el abandono de esta última (Saldanha 1988: 36; Serrão 1989: 36).

\footnotetext{
Este encalado es posterior al rejuntado original y previo a las pinturas, lo que indica un uso o adecentamiento intermedio de este espacio en el que se encalan únicamente la sillería y la parte superior del muro oeste de la cabecera (UE 1610, Etapa I/II).

8 También gótica, de finales del XV, es la imagen en piedra del príncipe de los apóstoles conservada en la parroquia de San Pedro de Penaferrim (Pereira 1975: 181-193), y que algunos autores consideran pudo albergarse en origen en la iglesia junto al castillo (Rodil y Carvalho 1995: 13).
}

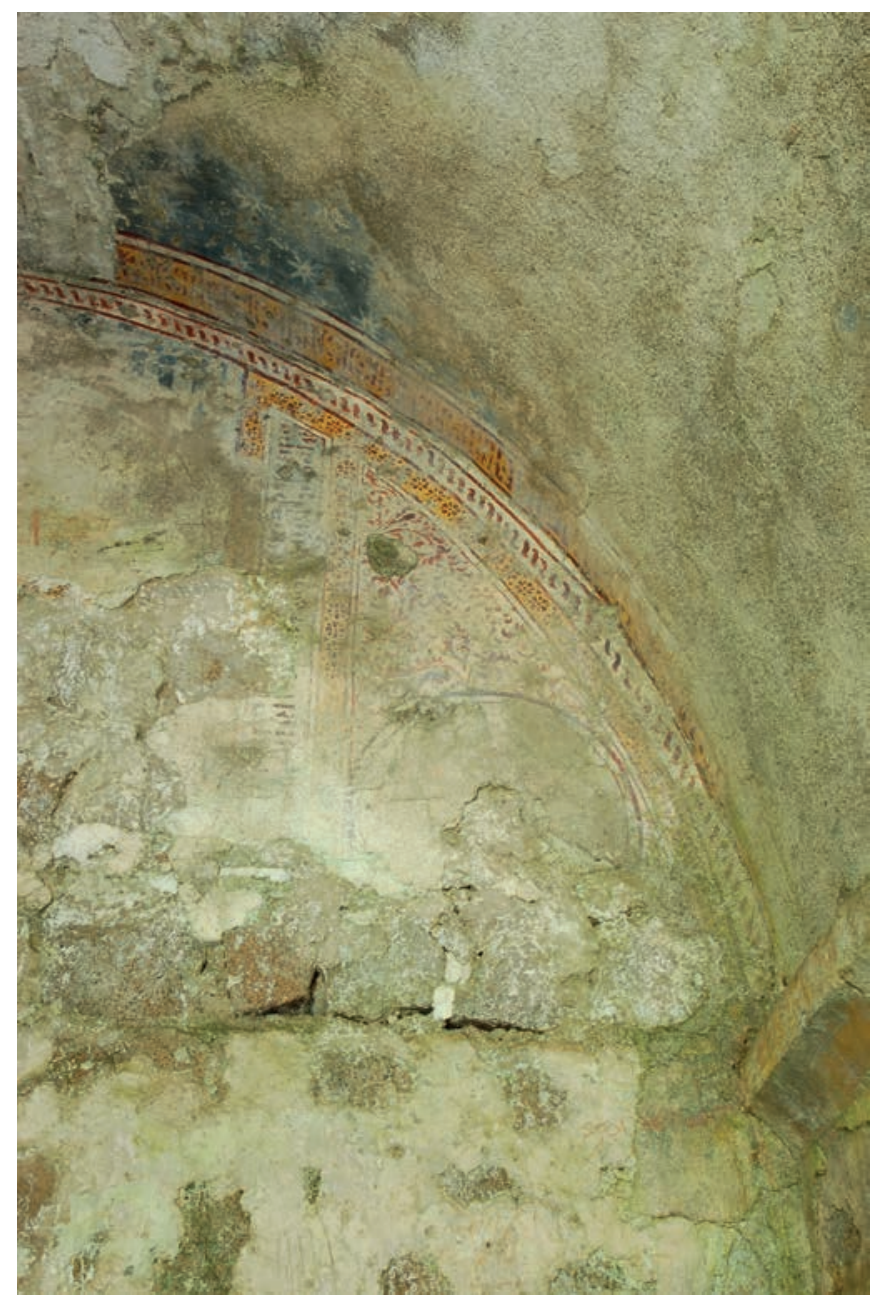

Figura 20. Restos de las pinturas de la bóveda del ábside de la iglesia de Canaferrim.

Antes de concluir la explicación de esta segunda etapa, debemos tratar de la fecha de construcción de la cisterna de la fortificación (Fig. 21). Esta obra es de planta rectangular y está jalonada al interior por seis pilares que sirven de asiento a los arcos fajones que sustentan su bóveda de cañón (restaurada en la Etapa VI). Está realizada con sillería granítica que remata en los muros longitudinales en una sencilla línea de imposta continua (UE 1500). Se accede a su interior por una puerta en el testero sur con remate apuntado, desde donde una escalera desciende hasta la cota de suelo (Fig. 22). En el centro de este suelo existe una pileta circular para facilitar su limpieza.

La sillería utilizada para la construcción de esta cisterna es reaprovechada. Así lo evidencian: a) sus aristas escantilladas y ángulos redondeados; b) las marcas longitudinales existentes en el primer pilar suroeste de la cisterna, interrumpidas por la obra indicando que no fue este su lugar original; c) el escaso número de marcas 


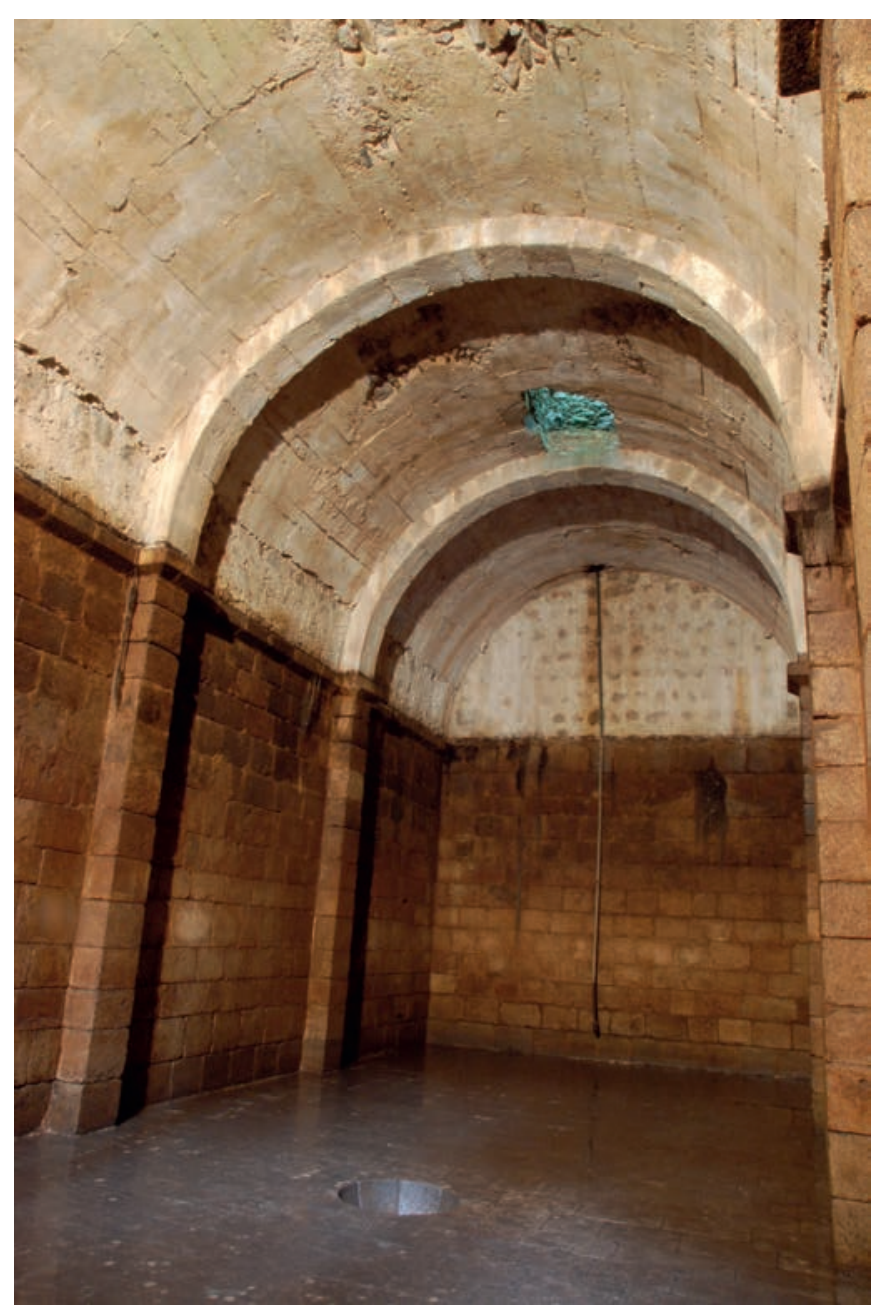

Figura 21. Cisterna del castelo con la bóveda reconstruida (Etapa VI). de cantero en relación con el número total de piezas de sillería de la cisterna, que sugieren que probablemente otras se hallen ocultas por la reutilización; d) los problemas de acoplamiento de sillares resueltos con pequeños codos; y e) las huellas de pico realizadas para recibir argamasa y visibles en las caras externas.

El funcionamiento de esta obra, excavada en la vaguada o talweg del barranco, es similar al de un pozo. La fosa realizada para su construcción corta el nivel freático del terreno que filtra el agua al interior de la cisterna. Esto explica la escasa variación del nivel de agua en su interior, que mantiene las mismas constantes que el freático del terreno, con escasas oscilaciones dadas las condiciones climáticas de la zona y las características geomorfológicas del macizo subvolcánico de Sintra. A la función evidente de recoger y almacenar el agua de la naciente del arroyo para uso de los habitantes del castillo, se debe unir la de protección del lienzo de muralla oriental de las aguas de escorrentía del barranco. $\mathrm{Y}$ es que la construcción de este último, transversal a la vaguada, implicó el cierre artificial de la misma y, necesariamente, la acumulación de agua en su base, puesto que no existen, según los datos que manejamos hasta el momento, elementos originarios de desagüe del agua en la parte inferior de la muralla.

Esta segunda función del aljibe implicaría, de comprobarse, su construcción coetánea o inmediatamente posterior al lienzo este de la muralla. La existencia de marcas de cantero en la sillería reutilizada en la

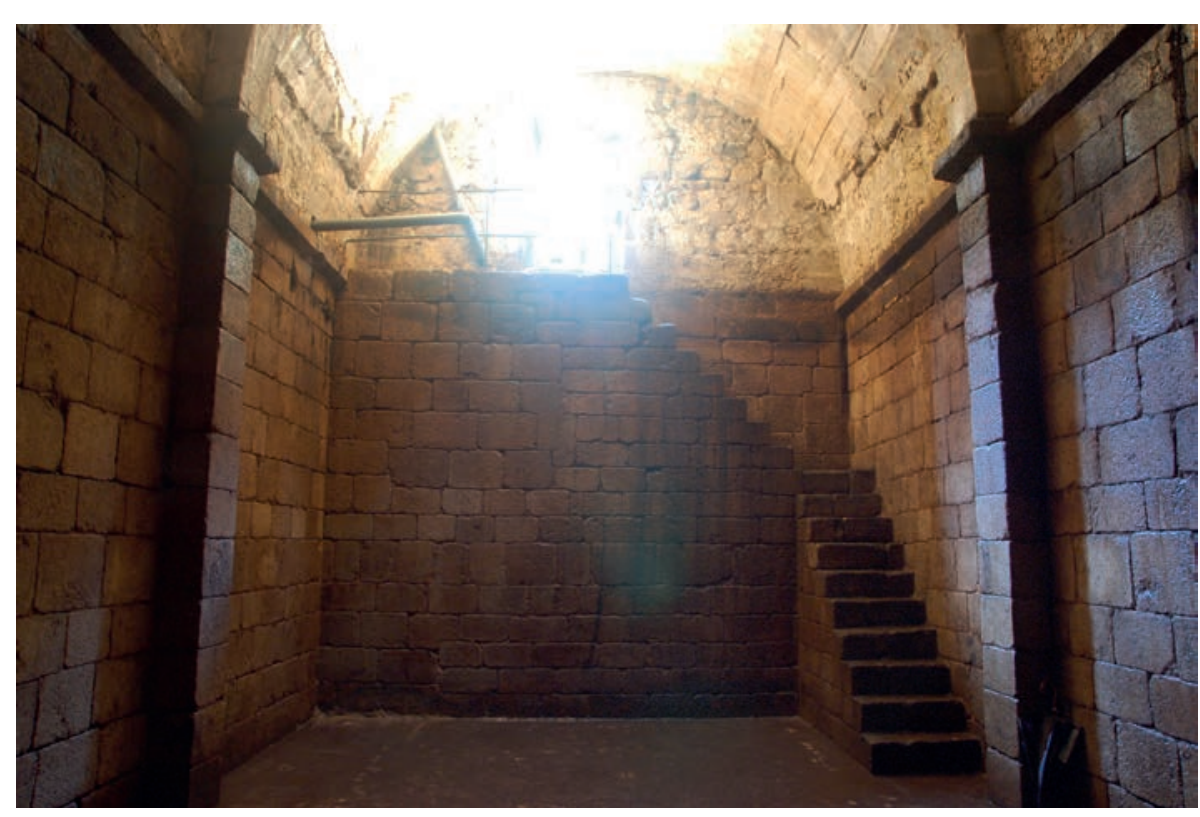

Figura 22. Escaleras de sillería reutilizada en el acceso a la cisterna del castelo. 
construcción de la cisterna, acota una fecha post quem para la construcción del edificio que originariamente empleó esta sillería: finales del siglo XI - principios del XII (Esquieu y Hartmann-Virnich 2007: 331-358). La reutilización de este material para la cisterna de la fortificación ha de ser, por tanto, necesariamente posterior al s. XII, sin que se pueda precisar con mayor exactitud su datación. Por otro lado, tampoco es plausible antes de esta fecha la erección de una bóveda con fajones que cubra una luz de $6 \mathrm{~m}$ (Utrero 2006: 120-121).

También hemos de tener en cuenta, dentro de las hipótesis de construcción de la cisterna, las características de su puerta de acceso con remate apuntado. Aunque las piezas se recolocaran en una restauración posterior (Etapa VI), es probable que éstas sean las originarias de la estructura, lo que permitiría inferir una cronología gótica (siglos XIII-XIV) para la puerta. De esta forma, parece posible asegurar la edificación del aljibe en un momento posterior a la primera etapa, entre los siglos XIII y XIV, en posible relación, por tanto, con las grandes reformas llevadas a cabo en el castillo en la Etapa II.

\subsection{Etapas III, IV y V (siglos XV-XVIII lienzo este; siglos XVI-XIX iglesia). Estancias intramuros y obras de época moderna}

[Muralla: A 116, UUEE 1211 1220; A 117, UUEE 1205 1212 1213; A 118, UE 1224; A 119, UE 1221; A 120, UUEE 12251226 1227; A 131, UE 1214; A 121, UUEE 102612081209 1218; A 122, UE 1021; A 128, UE 1219.
Iglesia: A 315, UUEE 1606, 1607; A 317, UE 1609; A 318, UE 1611; A 319, UE 1625; A 320, UE 1629; A 321, UE 1630]

La Etapa III en el Castelo dos Mouros supone la construcción de una o dos grandes estancias adosadas al interior del lienzo este de la fortificación (denominadas comunmente "caballerizas"), con dos puertas originales en el lado oeste (UE 1211). Su aparejo es de mampostería de módulo medio, regularizada con verdugadas de lajas que se disponen a veces a sardinel, aunque no llegan a completar las hiladas, y está construido de nuevo con andamios pasantes y una cimentación poco potente. La altura de sus muros, como mínimo la del adarve actual, y su amplia luz, de casi $9 \mathrm{~m}$, implicó necesariamente la colocación de una viga de madera para su cubierta, intermedia, longitudinal y sustentada por varios pilares (Figs. $23 \mathrm{y}$ 24). Durante los trabajos de excavación arqueológica realizados en el interior de las habitaciones aparecieron cimientos de estos posibles pilares, alineados en su eje longitudinal.

En un segundo momento, probablemente no alejado en el tiempo (Etapa IV), estas estancias sufrieron una remodelación que supuso la división en dos alturas de la habitación norte (AA 117, 118, 119, 120 y 131), siendo posible establecer una relación entre este forjado y la construcción del muro que divide las habitaciones (UE 1220; que pertenecería, por tanto, a esta Etapa IV), ya que no existen indicios de este suelo alto en la habitación sur. La construcción de este forjado interfiere

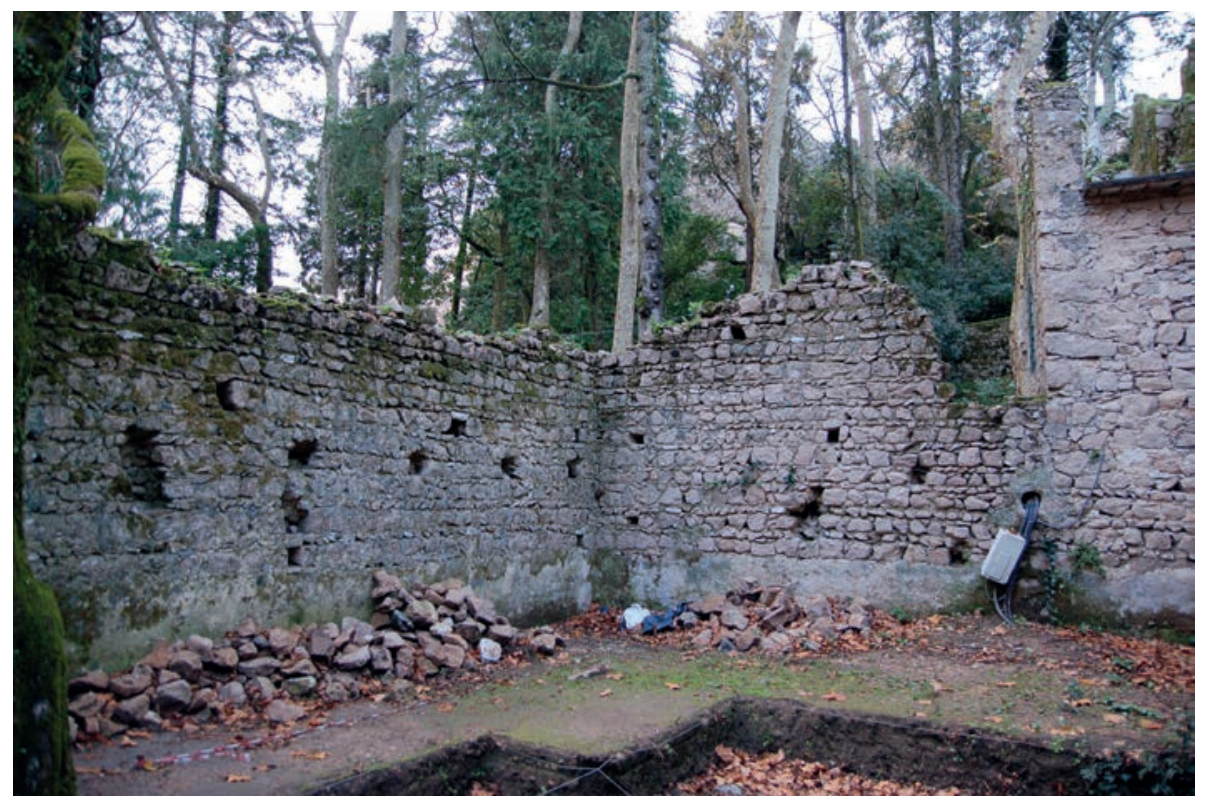

Figura 23. Muros oeste y norte en la estancia norte (UE 1211), adosada al interior del lienzo este. 


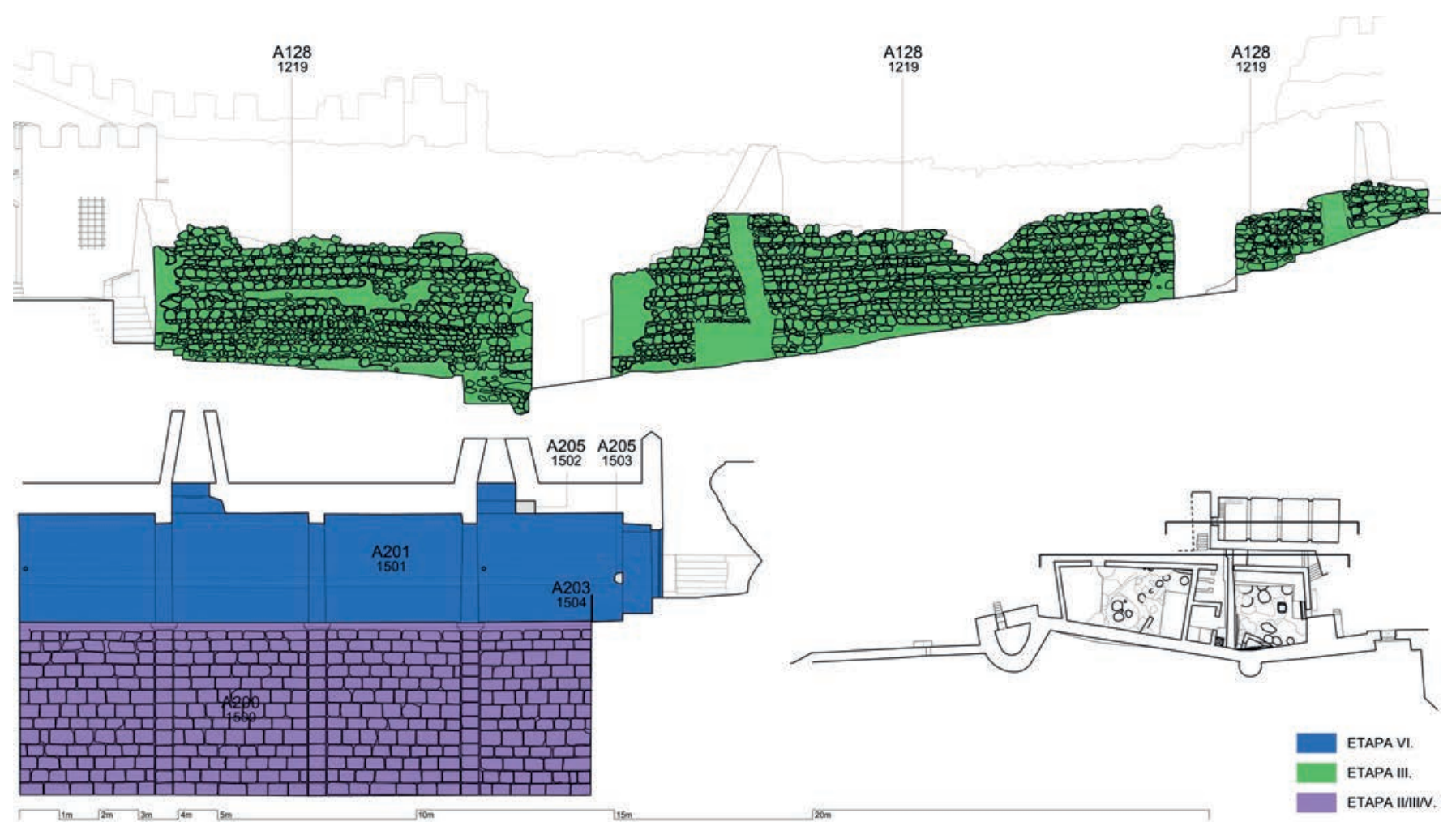

Figura 24. Habitaciones adosadas al lienzo este (interior) y cisterna del castelo. Secciones longitudinales con lectura estratigráfica.

con la altura de la puerta norte de la habitación que, sin embargo, no conserva indicios de haberse cegado por tal motivo.

En la etapa V, el abandono de ambas estancias produjo el paulatino derrumbe de sus cubiertas y la ruina de la parte superior de sus muros perimetrales ${ }^{9}$ (UE 1219). La ausencia de cubierta en las habitaciones no impidió su reaprovechamiento posterior. En ambas estancias se adosaron al muro divisorio, sobre un nivel de escombros, una serie de muros bajos de mampostería, de los cuales solo se conservan los de la estancia norte, probablemente establos o corrales para ganado menor (UE 1209). A esta obra pertenecen también: a) el enfoscado que recubre la primera estancia y el sector norte de la segunda; b) el desagüe que atraviesa el lienzo de muralla en el paño $2 / 3$ y que daría servicio a estos corrales (UUEE 1208 int. y 1026 ext.); y c) la colocación de una puerta de madera (UE 1218) en la entrada de la estancia norte (Fig. 25).

Una cita contradictoria del escritor inglés James Edward Alexander en 1834 (1803-1885) señala la existencia

\footnotetext{
9 Y quizá también, como consecuencia, se acabaron arruinando la parte superior del paño 2/3 y de la torre 3 (UE 1017, Etapa VI), y la parte superior del paño 1/2 y de la torre 1 (UE 1017, Etapa VI).
}

en el interior del recinto, y cerca de la cisterna, de lo que “(...) pareciam ser filas de estábulos, os telhados suportados por pilares de secção quadrada (...)", lo que permite plantear dos fechas para las cubiertas de las estancias y para la construcción de estos habitáculos. La mención de este autor a "filas de estabulos" dentro de las estancias podría referirse al uso ganadero descrito en esta etapa (Etapa V), lo que implicaría una fecha de construcción y abandono de las mismas anterior a su cita. Sin embargo, el escritor inglés menciona también la cubierta de las estancias con "(...) os telhados suportados por pilares de secção quadrada (...)", lo que no cuadraría con el techado propio documentado para los establos, que se habrían construido una vez arruinada la cubierta de las habitaciones, sino la necesaria para soportar la originaria de las estancias. Esto supondría la construcción de los habitáculos ganaderos en una fecha posterior a la visita de $\mathrm{J}$. E. Alexander, y más cercana, por tanto, a la intervención del monarca D. Fernando II en el castillo (Etapa VI). Una tercera solución podría resolver la aparente contradicción, de aceptar que la función de las estancias fuera estabular desde su origen, cuando aún no se habían construido los habitáculos supuestamente ganaderos.

Por otro lado, y también dentro de la Etapa $V$ de la fortificación, se cegó el portillo existente en el extremo 


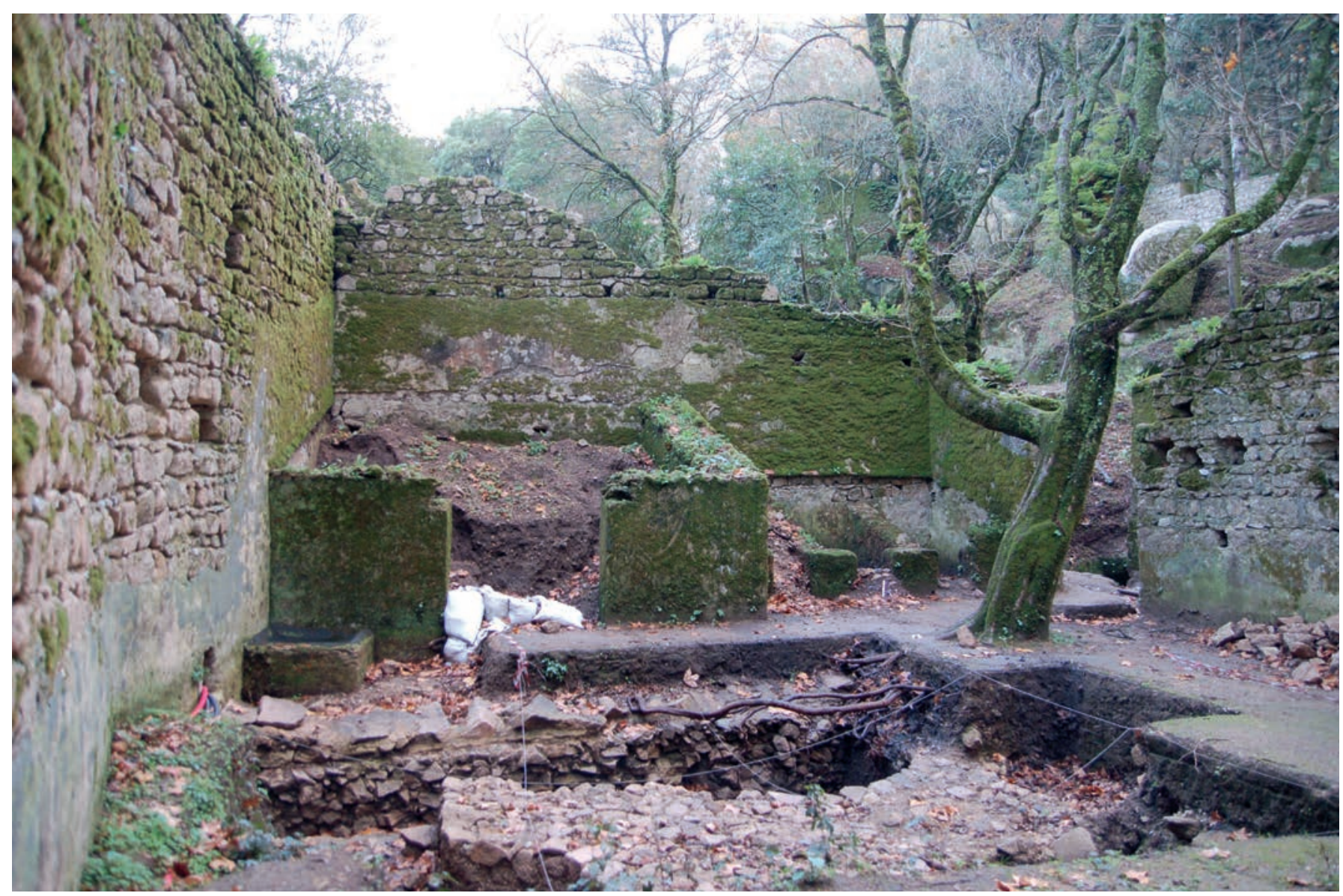

Figura 25. Restos de estructuras para uso ganadero en la estancia norte, adosadas al muro UE 1220.

norte del paño 3/4 (UE 1021), lo que implica un importante cambio de usos en la fortificación, al cerrarse un acceso de uso histórico.

Tanto la construcción de las estancias en la Etapa III, como su remodelación en la Etapa IV, parecen relacionarse con un uso habitual del castillo no muy alejado cronológicamente de las grandes reformas de la Etapa II. Su abandono y ruina posterior, reflejado en la descripción del escritor J. E. Alexander (1834), indica una fecha posterior para la Etapa V, probablemente cercana a la intervención del monarca D. Fernando II (Etapa VI).

También en la iglesia de Canaferrim se documentan pequeñas actividades encuadrables genéricamente en un horizonte cronológico que va desde el siglo XVI hasta la primera mitad del XIX (Fig. 26). Se trata fundamentalmente de huellas negativas, que reflejan el abandono del uso original de la iglesia y la asignación de nuevas funciones que, en el caso del ábside, implican: a) la reducción de la luz del vano del testero (UE 1609); b) la colocación de un cierre tipo puerta en el arco de embocadura, vinculable a los huecos abiertos en las jambas (UE 1606) y en el zócalo del arco (UE 1607); c) la colocación de otros elementos de cierre como el pequeño rebaje en su imposta sur (UE 1611). Los huecos de las jambas y el zócalo del arco de la cabecera fueron reflejados en el grabado de la iglesia realizado por William Burnett (1830) (Fig. 27) ${ }^{10}$, por lo que ya en esa fecha habían perdido su uso. Por el contrario, no aparecen dibujadas otras huellas para colocar una reja de hierro, existentes en los fustes, capiteles e intradós del mismo arco, lo que indica su colocación en una fecha posterior (Etapa VI).

Otras acciones también documentadas en la iglesia, y pertenecientes a este segmento temporal, resultan más difíciles de interpretar, como las dos gorroneras del vano del muro norte (UUEE 1629 y 1630), ya que resulta imposible su uso simultáneo como encastres de una puerta de madera.

\footnotetext{
10 En el Archivo Histórico de la Biblioteca Municipal de Sintra, en adelante AHBMS (Síntesis documental proporcionada por M. J. de Sousa).
} 

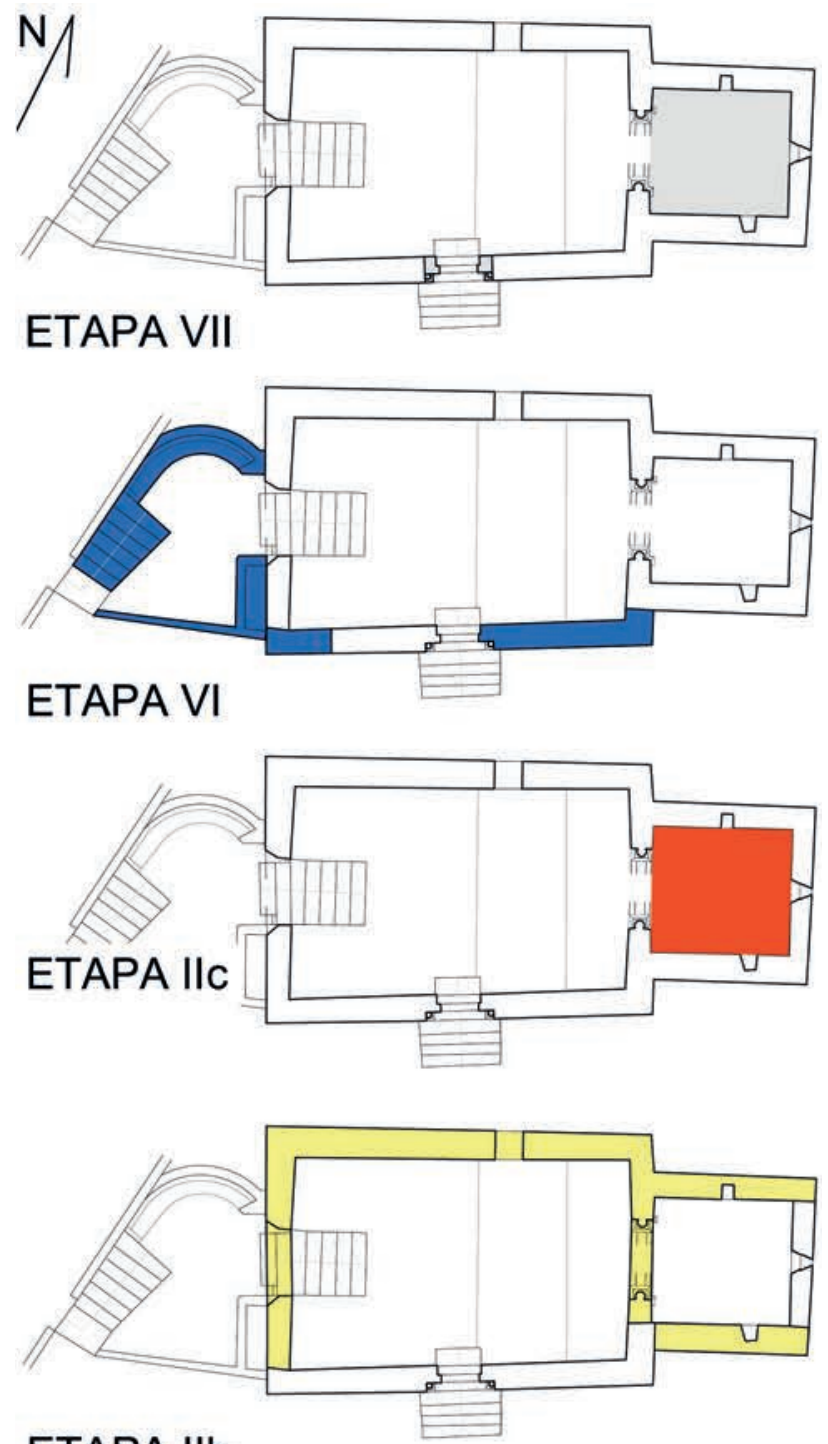

ETAPA IIb

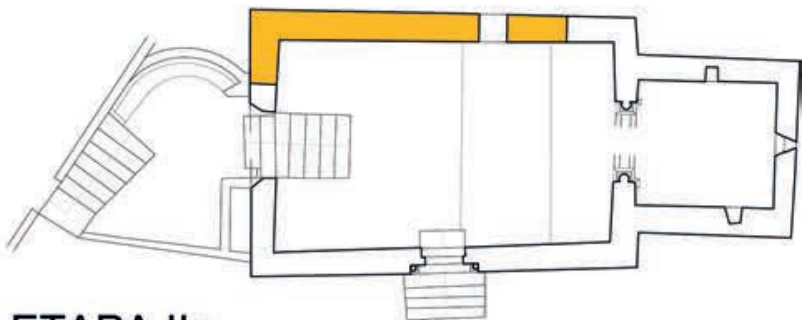

ETAPA lla

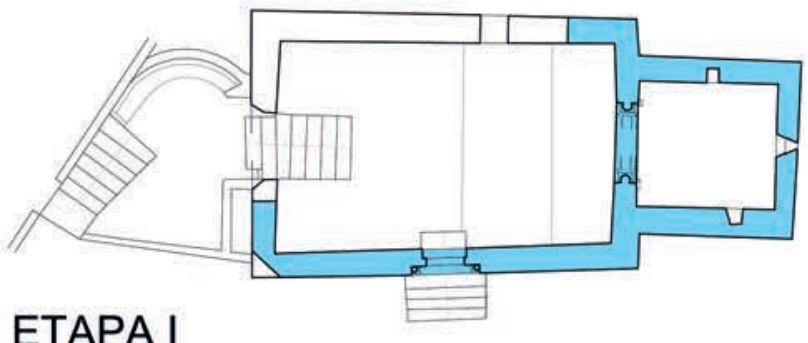

ETAPA I

Figura 26. Iglesia de S. Pedro de Canaferrim. Síntesis de la evolución en planta.

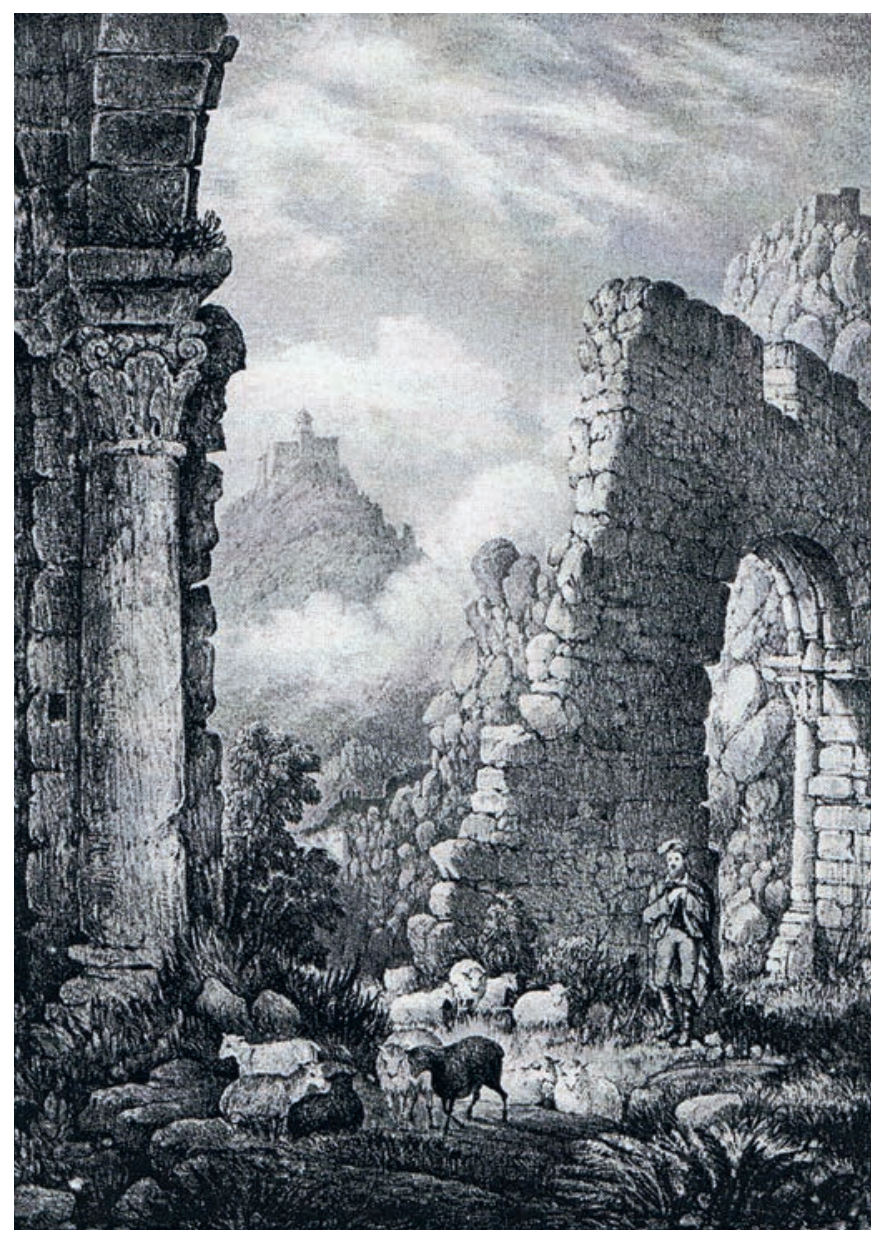

Figura 27. Grabado de la iglesia por W. Burnett (1830; síntesis documental M. J. de Sousa).

Finalmente, en el encadenado del muro noroeste de la nave, la huella de un muro perpendicular (UE 1625) podría inferir la existencia de un espacio habitacional adosado por el norte. Aunque no poseemos más datos que confirmen tal hipótesis, podemos aducir a favor de la misma la existencia del vano septentrional, que permitiría la circulación entre nave y una estancia adosada, como ya se ha señalado (Etapa IIA) (Saldanha 1988: 37).

\subsection{Etapa VI (siglo XIX). Intervención romántica de $D$. Fernando II}

[Muralla: A 112, UUEE 1017 1232; A 113, UUEE 1013 1233; A 114 UUEE 10081239 1241; A 123, UUEE 1025 1210; A 133, UE 1236. Iglesia: A 307, UUEE 1616 1622; A 308, UUEE 1604 1615; A 309, UE 1626; A 310, UUEE 1613 1627; A 313, UE 1602; A 316, UE 1608; A 322, UE 1631; A 323, UE 1632; A 325, UE 1634. 
Cisterna: A 201, UUEE 15011509 1510; A 202, UUEE 15051506 1508]

Las actividades de esta etapa se deben a la intervención del rey consorte D. Fernando II (1816-1855), quien convierte el conjunto, perdida la función defensiva, en un elemento de recreo, un jardín abierto al público con características románticas ${ }^{11}$. Pero la actuación regia procura también la "restauración" de la ruina, que había hecho mella de forma importante al menos en el paño $2 / 3$ y en la torre 3 (UE 1017), y puede que en la parte superior del paño $1 / 2$ y en la torre 1 del lienzo este ${ }^{12}$.

Aunque la "restauración" tenía como objetivo la restitución de las estructuras respetando su originalidad $^{13}$, introduce nuevos elementos de carácter decorativo (plantaciones, jardineras, bancos y, quizá, los merlones de la muralla) y funcionales (caminos, ensanche del adarve, escaleras, etc.), para acondicionar las estructuras de la fortaleza a la visita. Lamentablemente, tanto estas intervenciones regias como las posteriores estatales de la DGEMN (Etapa VII) no están documentadas, por lo que, aunque diferenciadas por sus relaciones estratigráficas y sus distintas tipologías, nos dejan la duda en muchas ocasiones de su debido encuadre, sobre todo cuando las segundas parecen imitar a las primeras.

Bajo el ideario romántico se hace transitable el muro sobre la puerta principal, realizando escaleras de acceso a la torre 1 y al adarve sobre la puerta, que se reconstruyen, o construyendo bancos, jardineras y almenas en la torre 1 (A 113; Fig. 28). Otros espacios, en cambio, se convierten en ruina romántica, un decorado sin ninguna función, como la torre 3 , que fue reconstruida y cuyo interior se forró de mampostería ${ }^{14}$ (A 114; Figs. 29 y 30). Lo mismo podemos decir sobre el recrecido del paño $3 / 4$ o el del extremo meridional del paño $2 / 3$, con merlones piramidales como los de la torre 1 . El

\footnotetext{
11 En línea con otros proyectos que se llevan a cabo en estas fechas en la villa (Serrão 1989: 67; Pereira 1995: 357-362).

12 En la parte superior del paño $1 / 2$, tanto al interior como al exterior de la muralla, se ha documentado una solución de continuidad horizontal (UE 1232), que no presenta señales de ruina, ni de superficie de uso. Sin embargo, por su correlación en altura con el adarve situado más al sur, podríamos interpretar esta cota como la del antiguo paso sobre la puerta principal. La obra sobre esta superficie (UUEE 1013 ext. 1233 int., Etapa VI) presenta además diferencias tipológicas con la fábrica inferior (Etapa II) y se extiende también por la parte superior del cuerpo de la torre 1 .

13 “(...) será obrigado a concervar todas as muralhas e vestigios antigos que tornão aquelle Lugar Monumento de recommendação e que bem longe de os deteriorar os augmentará fazendo n'elles todos os reparos necessários, sem que de forma alguna altere a sua Architectura" (Síntesis documental de M. J. de Sousa).

14 Algo que también pudo constatarse en su excavación (Sousa 2013: 816).
}

mismo sentido tendrían otros elementos menores como una puerta de hierro en el acceso al castillo (UE 1236) o las evidencias de carteles en su entorno. La obra de la restauración se evidencia por su fábrica homogénea

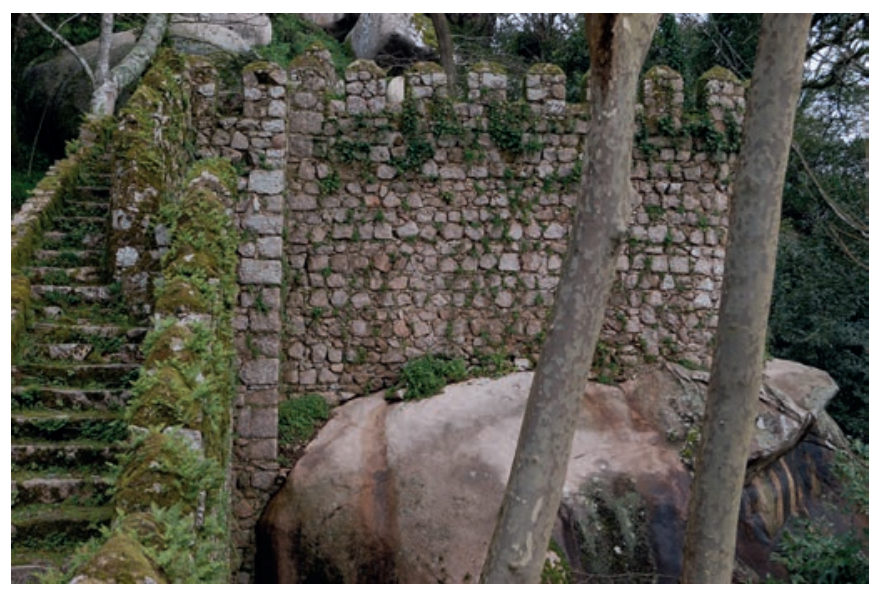

Figura 28. Restauración romántica de la torre 1 y escaleras de acceso al adarve.

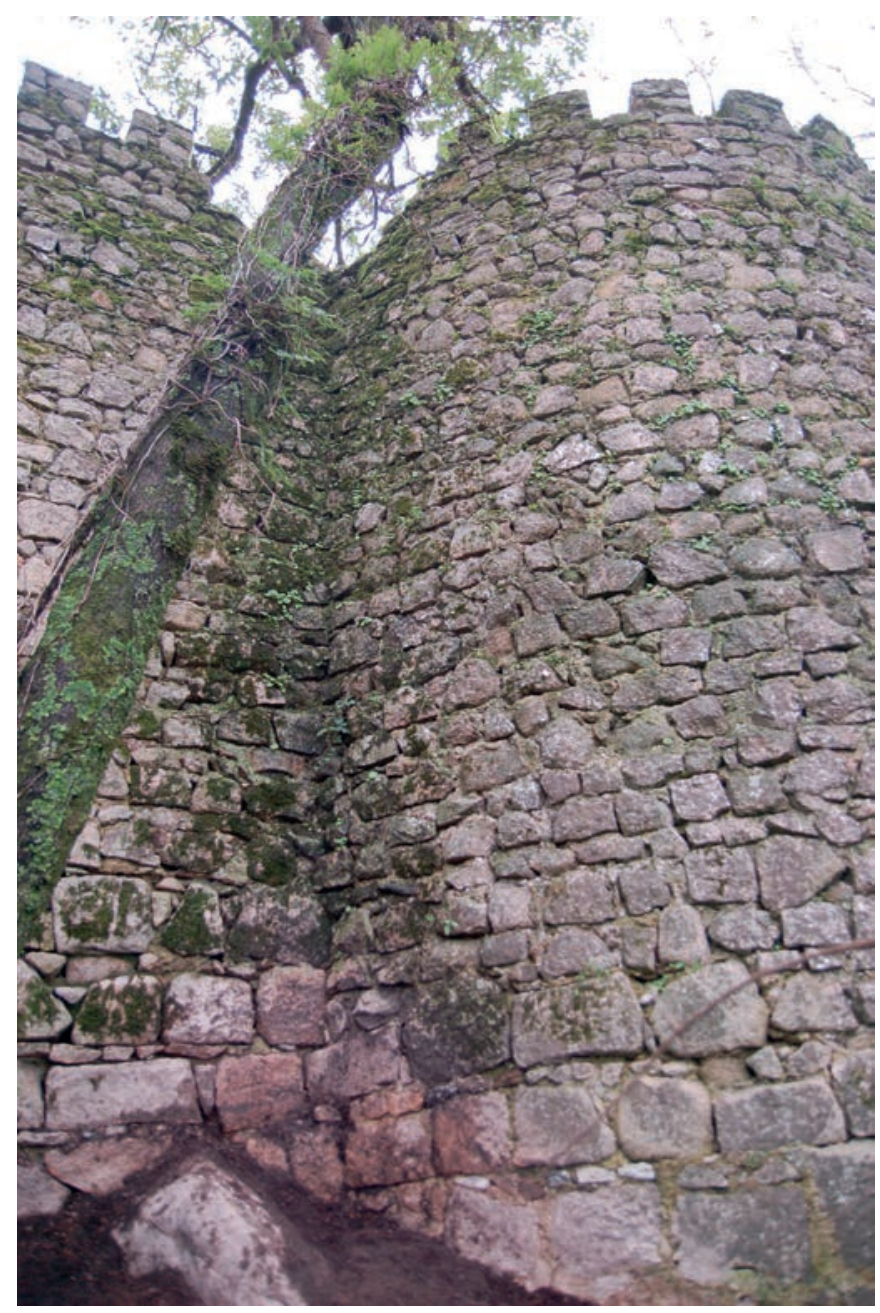

Figura 29. Restauración de Fernando II en la torre 3. 


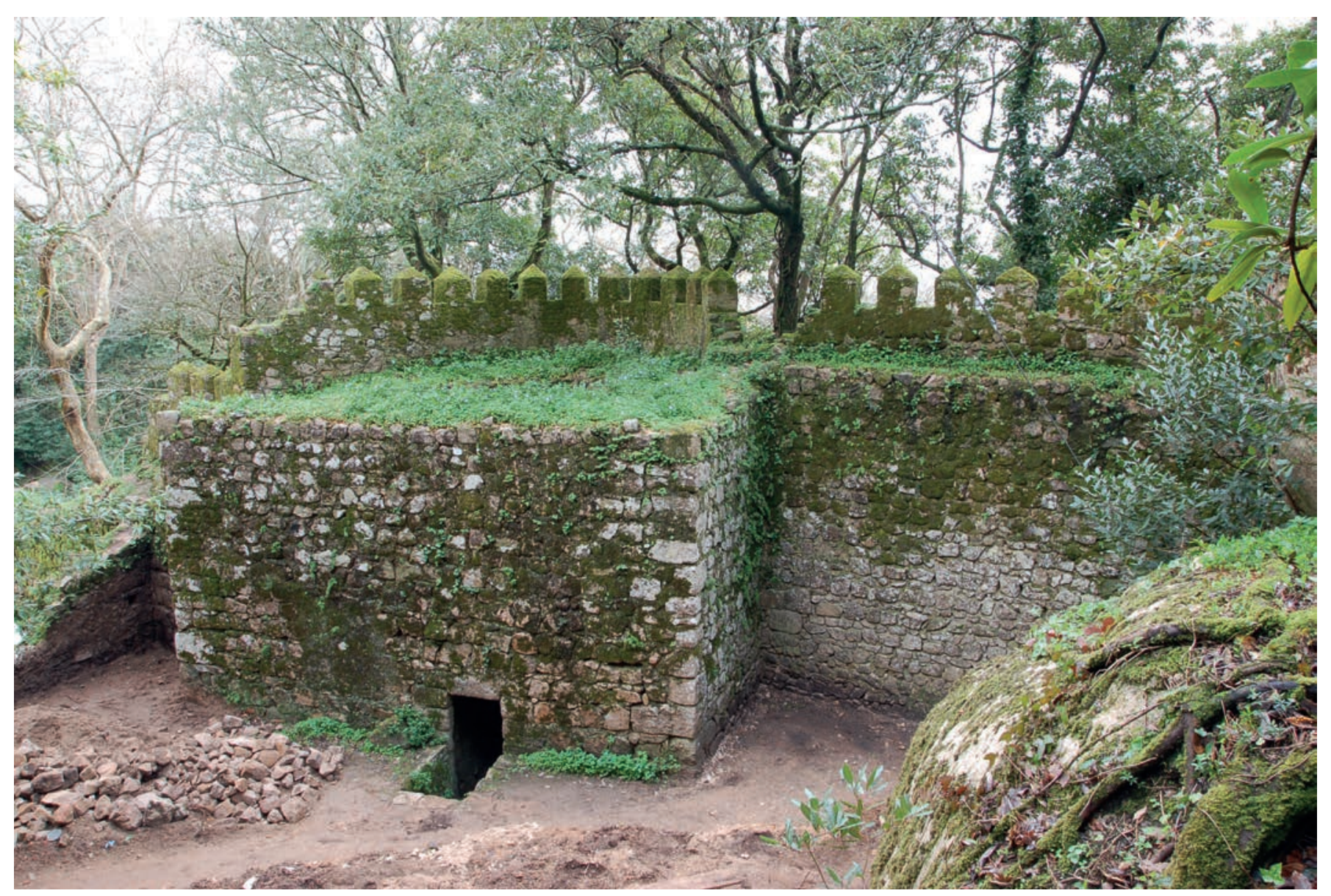

Figura 30. Proyección de la torre 3 hacia el interior de la fortificación.

de mampostería sin concertar, de módulo cuadrangular, dispuesta en hiladas regulares con algunos ripios y construida sin mechinales.

Similares características presenta la intervención de D. Fernando II en la capilla del castelo: evitar el avance de la ruina y monumentalizar su espacio, perdida su función cultual. Ya sin cubierta en esas fechas, el edificio presentaba una importante ruina en las dos esquinas meridionales de la nave, que afectaba a los muros sur y oeste y, muy especialmente, al extremo este del muro meridional (UE 1616). Habían sido robados además los elementos de sillería del acceso oeste a la nave, con el subsiguiente deterioro del vano (UE 1622).

La intervención restauradora estuvo muy localizada, como demuestran dos grabados del edificio de la primera mitad del XIX, el primero del ya citado William Burnett, y el otro de Clémentine de Brélaz (1840; Fig. $31)^{15}$. Ambos son previos a la obra del monarca y repre-

\footnotetext{
15 Ambos en el AHBMS (Síntesis documental proporcionada por M. J. de Sousa).
}

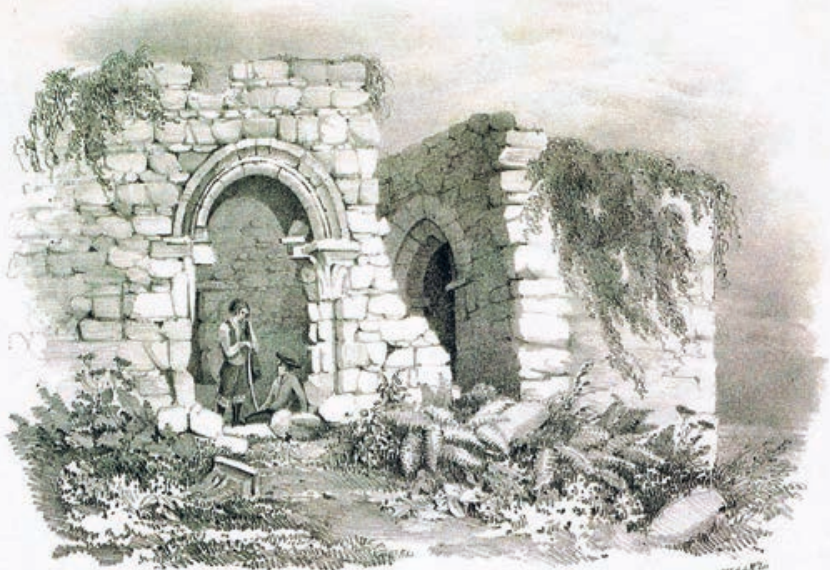

Figura 31. Grabado de la iglesia por C. de Brélaz (1840; Cachado 2009).

sentan de forma clara la ruina de la esquina sureste de la nave, apreciándose además en el segundo, la ruina parcial de los elementos decorativos de la puerta sur de la iglesia (Cachado 2009: 33). La actuación de Fernando II quedó limitada, por tanto, a la reconstrucción de las 


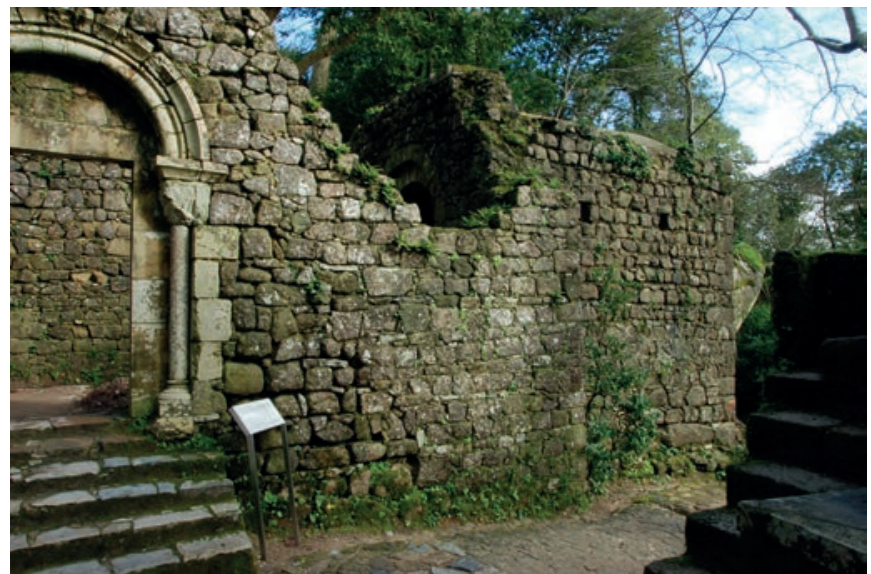

Figura 32. Esquina sureste de la nave de la iglesia, restaurada por Fernando II.

esquinas del muro sur (UE 1604 y 1615), con fábricas tipológicamente similares a las del castelo en esta etapa, y que presentan también características románticas, con su remate escalonado imitando una ruina (Figs. 32 y 33 ). Además se colocaron jardineras, se plantaron árboles incluso en el interior de la nave, y se construyeron las escaleras que permiten entrar al templo por sus accesos sur y oeste (AA 309 y 310). También incluimos en esta etapa la colocación de una reja de hierro en el arco de entrada al ábside, cuyos huecos de anclaje son visibles en los fustes, capiteles e intradós del arco de embocadura (UE 1608). Por último, la reapertura de parte del umbral de la ventana del testero, parcialmente cerrada en la anterior etapa (UE 1634). Finalmente, la apertura de caminos provocó el desmonte de un muro en el extremo sur del testero del ábside, que interrumpía su recorrido (UE 1602).

Aunque la actividad reconstructiva en la iglesia fuese menor, la "excavación" de su interior dirigida por el barón Ludwig von Eschwege, supuso el vaciado casi completo del subsuelo en la nave y el ábside, sacando a la luz numerosos restos óseos, para cuya nueva sepultura se mandó construir el monumento situado frente a la capilla (Anónimo 1863: 177-178; Serrão 1980; Simões 1999: 32). Así se provocó la pérdida de datos, como se comprobó en las excavaciones arqueológicas efectuadas a finales del pasado siglo $X^{16}$ (Simões 1999: 31-73).

\footnotetext{
16 Las excavaciones $(1983,1993-1998)$, a las que ya hicimos referencia al principio del texto, se llevaron a cabo en el ábside y en la nave, al exterior en el lado norte y noreste, y al sur del templo, donde se documentó un área de necrópolis cristiana con varios niveles de enterramientos. En el interior del templo, en los escasos puntos donde el vaciado de la iglesia no había afectado de forma tan drástica a la estratigrafía del subsuelo, pudieron documentarse los restos del pavimento originario de la iglesia (Simões 1999: 37-45).
}

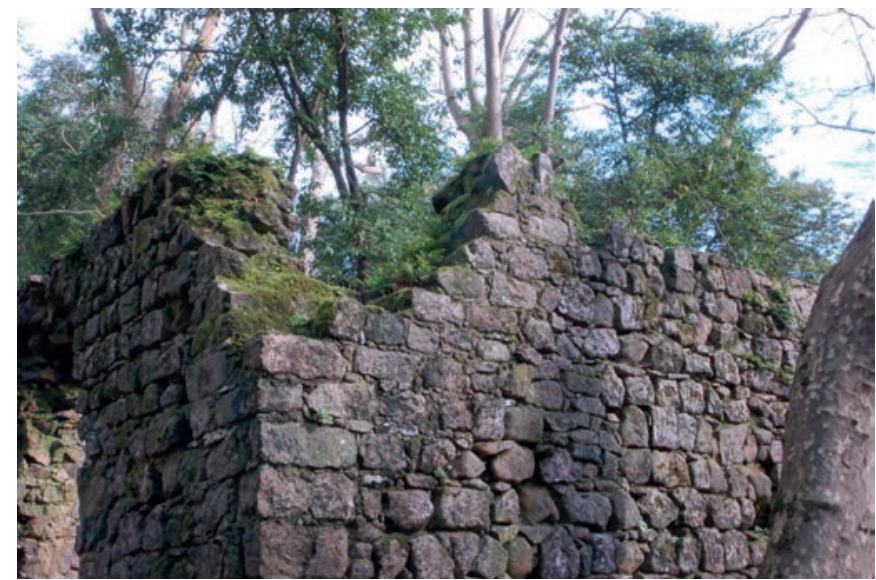

Figura 33. Ruina romántica en la esquina suroeste de la iglesia de Canaferrim.

También en la cisterna del castillo se observa una importante restauración que afectó especialmente a su bóveda y a su aspecto exterior. Sus características constructivas, la tipología de sus fábricas, las relaciones estratigráficas y su finalidad permiten encuadrar esta restauración en el conjunto de intervenciones del monarca D. Fernando II. La obra se evidencia por la diferencia constructiva entre la sillería de la cisterna (UE 1500, Etapa II) y la mampostería de sus tímpanos (UUEE 1509 y 1510), que asientan sobre los sillares supervivientes de los ángulos de la estructura, por encima de la línea de imposta. Además, se observan piezas reutilizadas en los tres arcos fajones de la bóveda (UE 1501), aunque su elevada altura dificulta diferenciar posibles restos originarios de otros restaurados. Por último, en el tímpano sur, el arco apuntado, construido solidariamente con éste, está claramente remontado. Esta reconstrucción del remate de la cisterna concuerda con la descripción previa que de su ruina hace el prior Antonio de Sousa en las Memorias Parroquiales de la iglesia de São Pedro de Penaferrim (1758; Rodil y Carvalho 1995: 13), quien describe la bóveda con "(...) duas fendas aruinadas (...)", hallándose “(...) bastantemente entulhada de Calisa, que cahio das duas fendas da abobada (...)".

Es coetánea también a esta obra la apertura existente en el arranque este de la bóveda, que sirve de rebosadero de las aguas de la cisterna (A 123). Comunica con una atarjea de mampostería y cubierta adintelada de lajas de granito, que atraviesa la estancia norte del interior del recinto $\mathrm{y}$, de nuevo, el tramo de muralla $2 / 3$ (a una cota inferior que el desagüe realizado para los establos en la Etapa V) ${ }^{17}$.

\footnotetext{
Esta atarjea discurre bajo la cota actual de suelo de la estancia y es parcialmente visible por las excavaciones efectuadas, que dejan ver, además, una importante reparación en su zona central.
} 
La reconstrucción de los tímpanos y de la bóveda de la cisterna no es una obra aislada y se debe relacionar con otras actuaciones que suponen una revisión historicista de este espacio, que en origen debió tener el trasdós de la bóveda vista. Así se deben entender los muros de remate del testero sur y el lateral este de la cisterna (UE 1505), y el consecuente relleno de tierras existente sobre la misma (UE 1508), que supone en la actualidad un foco de humedad para la bóveda (Fig. 34). A esta actuación pertenecen también el muro perpendicular al testero sur en su extremo oeste (UE 1506) y los cortes de la roca natural para propiciar el acceso al aljibe por su lado sur, o la llegada de un camino sobre la cisterna. Los dos respiradores de la bóveda, solidarios con ella, dos grandes orificios que comunican por sendos brocales de mampostería con la superficie, debieron tener una función similar, bien historicista, bien como elemento de protección del visitante o incluso con fines estéticos ${ }^{18}$.

\subsection{Etapa VII (siglo XX). Intervenciones de la DGEMN y otras posteriores}

[Muralla: A 124, UUEE 1009 1234; A125, UE 1217; A 126 UUEE 100310051006 1204; A 127, UUEE 1215 1228; A 129, UE 1243; A 130, UE 1244; A 132, UUEE 102412061207 1216; A 134, UUEE 10141015 1235; A 135, UE 1022; A 136, UE 1237; A 137, UUEE 1238. Iglesia: A 311, UE 1612; A 312, UE 1617; A 314, UE 1603; A 324, UE 1633; A 326, UE 1635. Cisterna: A 203, UUEE 1504 1511; A 204, UE 1507; A 205, UE 1503; A 206, UE 1502]

Las obras incluidas en la última etapa pertenecen en su mayoría a las intervenciones efectuadas en el castelo por la Direcção General dos Edificios e Monumentos Nacionais (DGEMN) en 1939, aunque otras obras efectuadas hasta la actualidad dificultan notablemente la diferenciación de las primeras.

En el lienzo este del castelo, la última etapa identificada supone un nuevo cambio en la función de la fortificación: de elemento de recreo romántico a monumento protegido de elevado interés turístico. La ruina

\footnotetext{
18 También en la cara sur del arco meridional, la cara norte del arco central y junto al ángulo del testero sur, se sitúan, en el tercio superior de la bóveda, tubos cerámicos, probablemente con la función análoga de respiraderos, que parecen construidos de forma solidaria con esta bóveda. Confundidos por algunos autores como parte de la obra originaria, han llevado a suponer erróneamente la funcionalidad del aljibe con agua de lluvia, que penetraría por estos orificios (Pereira 1957 [1975]: 211-212).
}

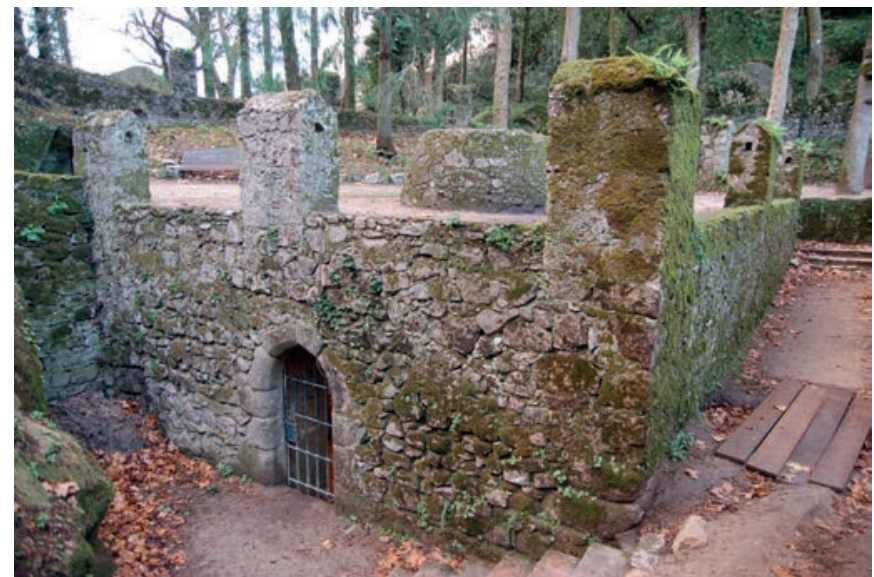

Figura 34. Reconstrucción historicista de la cisterna al exterior.

definitiva de los espacios estabulares de las estancias 1 y 2 en esta etapa (UE 1217), reitera la idea de un cambio en los usos y significado del edificio (Fig. 35).

La intervención de la DGEMN en la muralla se limitó a la restauración de una reciente ruina en el paño 1/2 ${ }^{19}$ (UUEE 1009 ext. y 1234 int.) donde, junto con la reconstrucción del lienzo, parte superior de la torre $2 \mathrm{y}$ parte del extremo septentrional del paño $2 / 3$, se realiza una escalera de acceso al adarve (UUEE 1204 int., 1003, 1005 y 1006 ext.). La nueva fábrica, de aspecto tupido, es de mampostería aristada y normalizada, que se dispone con estrechas hiladas de regularización y abundantes ripios verticales y horizontales, imitando en su hacer a las obras realizadas por el monarca D. Fernando II en su remate con merlones (Figs. 36 y 37).

A esta intervención debe pertenecer asimismo la construcción de la caseta de guarda junto a la puerta principal del recinto (A 127), justificada por la visita del monumento, aunque posterior estratigráficamente, $\mathrm{y}$ tipológicamente distinta a la reforma del paño $1 / 2$. También la colocación de letreros o carteles informativos en la puerta de acceso, de los que aún quedan las improntas (UUEE 1014, 1015, 1235).

En cuanto al relleno artificial de tierra del extremo sureste del recinto (UE 1243), probablemente nivelaciones de terreno para la adecuación de este espacio en relación con la construcción de unas escaleras de acceso a la torre 3 (UE 1244), dudamos de su adscripción a las intervenciones estatales de los años cuarenta para la adecuación del castillo o a su vinculación con

\footnotetext{
Que afectó tanto a la obra original (UUEE 10021007 ext. y 12031229 int.) como a las posteriores reformas históricas (UE 1231, Etapa II; UE 1233, Etapa VI).
} 

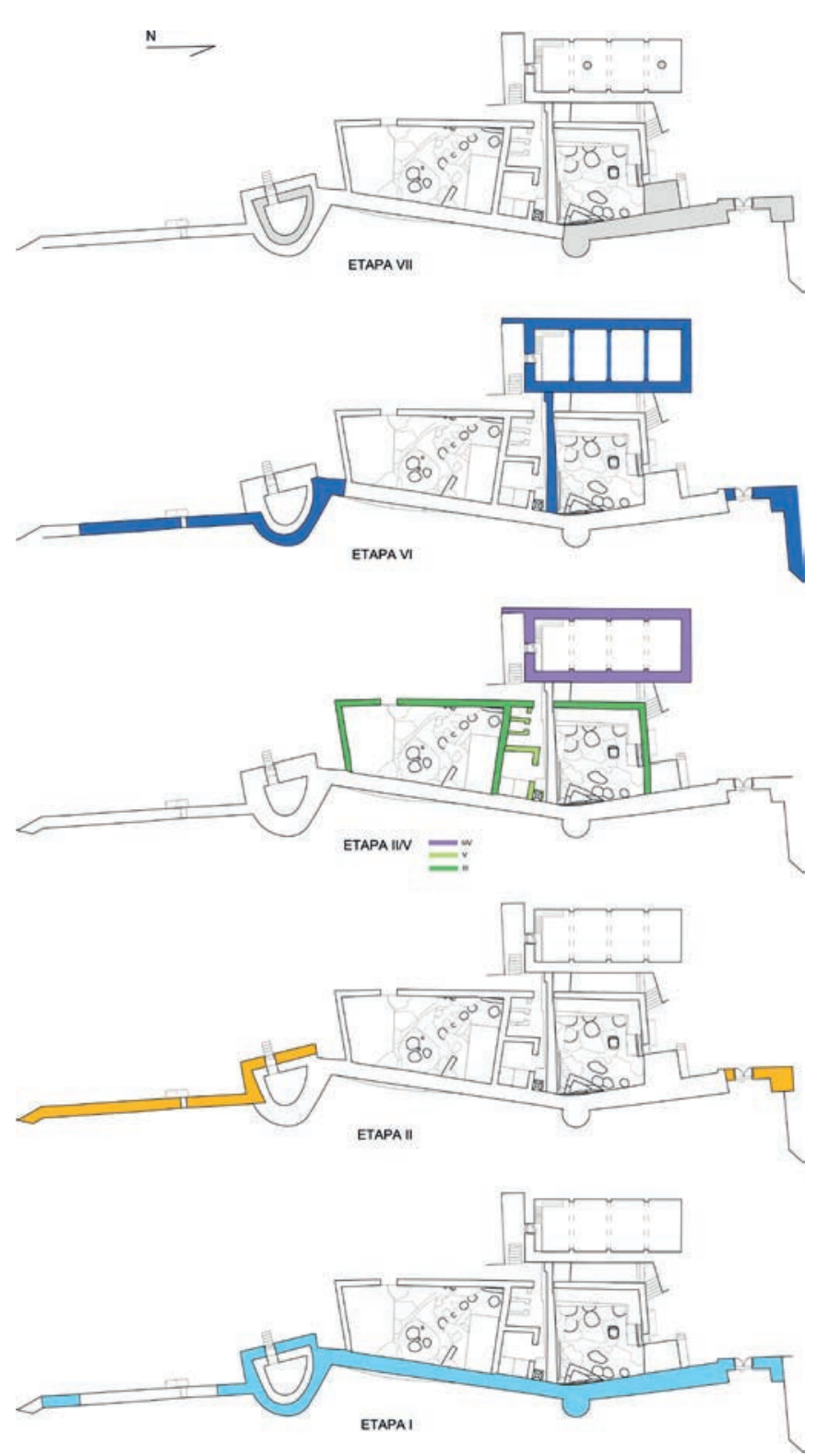

Figura 35. Castelo dos Mouros y su cisterna. Síntesis de la evolución en planta.

la obra de D. Fernando II y su restauración de la torre 3 (Etapa VI).

Finalmente, mencionamos la apertura del vano septentrional del paño 3/4 (UE 1022), anteriormente cegado, una acción contemporánea al relleno de tierras que acabamos de citar. Desconocemos el fin de tal acción que, según Pavón (1993: 24), implica convertir este postigo en un desagüe, hipótesis para la cual también faltan argumentos.

La restauración de la puerta sur de la iglesia de Canaferrim (UE 1612) pertenece a la intervención coordinada por la DGEMN en los años cuarenta del siglo

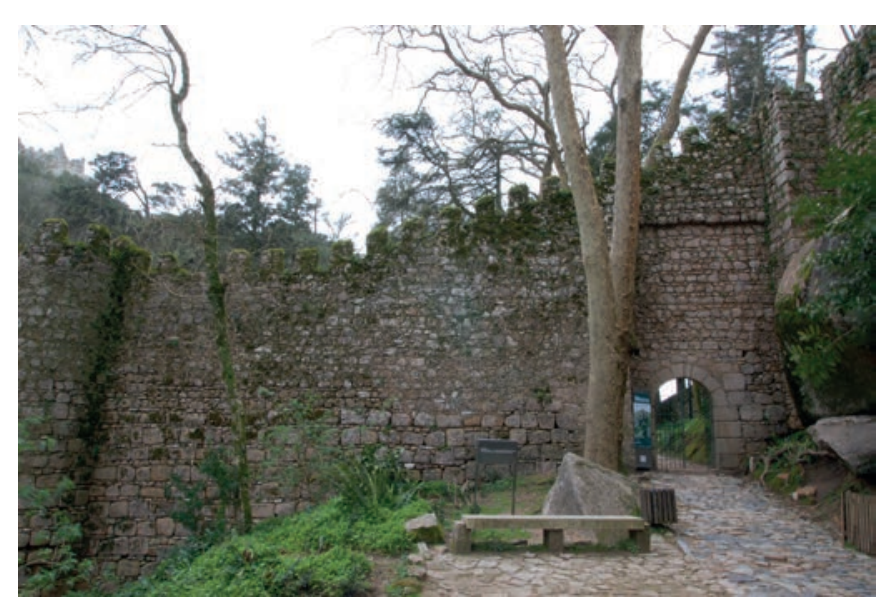

Figura 36. Reconstrucción contemporánea del paño 1/2.

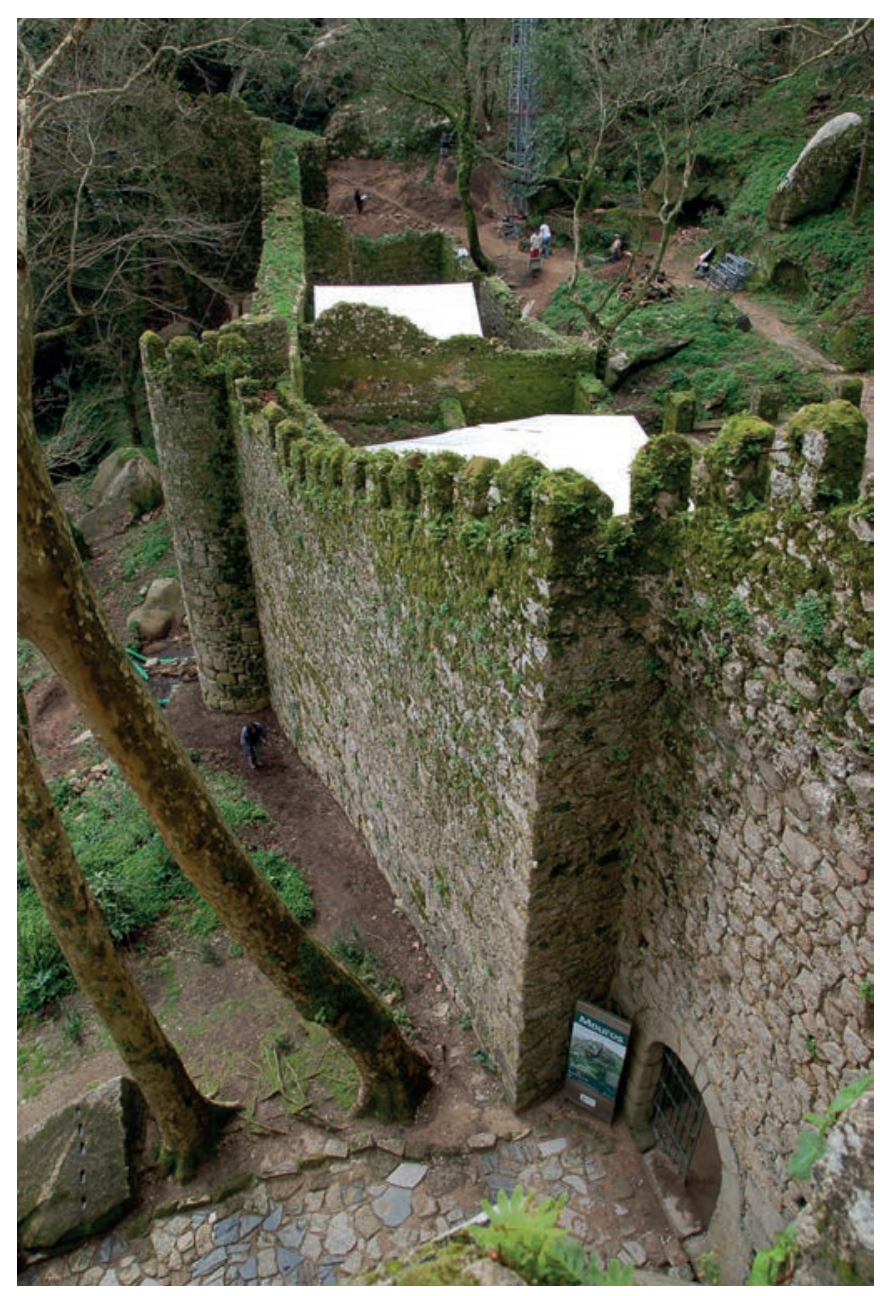

Figura 37. Merlatura contemporánea en el lienzo este del castelo.

pasado, con “(...) substituição de cantarias mutiladas"20, según reza el contrato de obras conservado. En ella, a pesar de utilizar la misma caliza ocre, se distingue de la

\footnotetext{
20 Síntesis documental proporcionada por M. J. de Sousa
} 
sillería originaria, la nueva de reposición o sustitución de las jambas interiores, dintel y algunas piezas exteriores por sus aristas vivas, juntas con cemento y cuñas, el marco de talla y la huella de la "gradina". También se sustituyó el tímpano de la puerta por otro de mampostería. Por su parte, la bóveda del ábside se cubrió con una capa de cemento ("encapotado", UE 1617) para estabilizar e impermeabilizar su rosca.

La cisterna recibió otras intervenciones decorativas y funcionales tanto de la DGEMN como posteriores: en su interior, la barandilla metálica que protege la escalera y la reja que cierra su acceso (A 203); y en el exterior, los forros de mampostería que probablemente recrecen los pozos de la cisterna (UE 1507) y que relegan su función a la de meros respiraderos y lucernarios.

\section{CONCLUSIONES Y NOTAS FINALES}

El estudio arqueológico de la arquitectura del lienzo oriental, la cisterna y la iglesia extramuros de São Pedro de Canaferrim, que forman parte del conjunto Castelo dos Mouros de Sintra, ha ofrecido como resultado una minuciosa observación formal, constructiva y estructural, datos inéditos y, sobre todo, una secuencia histórica interrelacionada con nuevas etapas y con una propuesta de datación más rigurosa:

1. Etapa I (segunda mitad del siglo XII - siglo XIII): cronología cristiana. Construcción del lienzo oriental del castillo con sus líneas principales, incluida la localización del acceso principal y un portillo en el extremo contrario. Construcción de la iglesia de São Pedro de Canaferrim.

2. Etapa II (siglos XIII-XIV): uso continuado de los edificios. Grandes reformas históricas tanto en la muralla (paño $3 / 4$ y acceso principal) como en la capilla (fundamentalmente muros norte y oeste), motivadas todas ellas por ruinas previas debidas a fallos en las estructuras, y construcción de la cisterna subterránea de la fortificación.

3. Etapas III, IV y V (siglos XV-XVIII lienzo este; siglos XVI-XIX iglesia): uso habitual de la fortaleza y abandono del uso originario de la capilla. Construcción y sucesivas reformas de las llamadas "caballerizas" en el interior del lienzo este del castelo (etapas III y IV) y ruina de estos espacios (etapa V).

4. Etapas VI y VII (siglos XIX y XX): "restauración" de Fernando II (etapa VI, siglo XIX), que afectó al conjunto con mayor impacto del que se suponía. En la etapa VII (siglo XX), actuaciones menores, fundamentalmente de consolidación de las estructuras.

La limitación del estudio del castillo a su lienzo oriental impide unas conclusiones generales extrapolables a todo el recinto fortificado, pero supone un importante avance al retrasar al menos la cronología de este tramo a la segunda mitad del s. XII o circa 1200, abandonando la propuesta islámica. Si bien, es evidente la necesidad de un análisis completo que haga extensible esta cronología a todo el conjunto o la matice para algunos restos concretos. No obstante lo dicho, es importante remarcar que, aunque los datos obtenidos en las excavaciones arqueológicas de la iglesia y del lienzo este de la fortificación evidencian una ocupación islámica previa a la construcción del tramo de muralla analizado, no poseemos indicio alguno que permita afirmar que tal ocupación estuviese vinculada a un espacio fortificado, al menos en el tramo analizado en la ladera oriental.

El estudio arqueológico de la arquitectura debe coordinarse con el estudio en profundidad tanto de la bibliografía, las fuentes documentales y las excavaciones arqueológicas del yacimiento; estudios ya iniciados correctamente por el equipo del Parque. De esta manera (relacionando adecuadamente las llamadas cronologías absolutas y relativas, o mejor dicho, mediante las contextualizaciones conseguidas por los análisis arqueológicos del yacimiento y el edificio histórico) se podrán abandonar o confirmar las hipótesis y asegurar y concretar las cronologías que hoy se proponen.

La experiencia de nuestro trabajo, y en esto Sintra no ha sido una excepción, nos invita a huir del tradicional abuso de los paralelos para datar los edificios. La secuencia estratigráfica, el análisis tipológico de los aparejos, los datos de la excavación arqueológica y la contextualización histórica han permitido nuestra propuesta, a la vez que se ampliaba la secuencia histórica del conjunto que se demuestra más rica de lo esperado.

\section{FICHA TÉCNICA Y AGRADECIMIENTOS}

Los trabajos efectuados en el conjunto del Castelo dos Mouros de Sintra dentro del ámbito de la Arqueología de la Arquitectura fueron encargados por la empresa gestora del conjunto monumental Parques de Sintra - Monte da Lua, S.A, en relación con la ejecución de 
obras de restauración y acondicionamiento turístico de algunas zonas del castillo (año 2011).

En los trabajos, realizados bajo la coordinación de L. Caballero (IH-CSIC), participaron M. A. Utrero, M. Barahona, J. I. Murillo y C. Cauce. El autor de la planimetría original es R. Martín.
Queremos añadir además una nota final de agradecimiento para la arqueóloga directora del Parque, Dña. María João de Sousa, por su esfuerzo y por toda la ayuda mostrada.

Todas las figuras reproducidas en este trabajo son propiedad de los autores.

\section{LISTADO DE ACTIVIDADES Y UNIDADES ESTRATIGRÁFICAS}

\section{Castelo dos Mouros}

\begin{tabular}{|c|c|c|c|c|c|c|}
\hline Etapa & Act & Nombre Act & $\mathbf{U E}$ & Nombre UE & Ant a Act & Post a Act \\
\hline 0 & 100 & Geológico & 1000 & Geológico & $\begin{array}{c}103104105 \\
106107111 \\
113300\end{array}$ & \\
\hline \multirow[t]{14}{*}{1} & 101 & $\begin{array}{l}\text { Fábrica desordenada al norte de } \\
\text { UE } 1200 \text { (paño } 1 / 2 \text {, lienzo este) }\end{array}$ & 1202 & $\begin{array}{l}\text { Fábrica desordenada al norte de } 1201 \text {, tramo } 1 / 2 \\
\text { interior }\end{array}$ & 102 & \\
\hline & 102 & $\begin{array}{l}\text { Solución de continuidad al sur de } \\
\text { UE } 1202 \text { (paño } 1 / 2 \text {, lienzo este) }\end{array}$ & 1201 & Corte vertical en el extremo sur de 1202 & 103 & 101 \\
\hline & 103 & $\begin{array}{l}\text { Parte inferior paño } 1 / 2 \text {, lienzo } \\
\text { este }\end{array}$ & 1200 & $\begin{array}{l}\text { Parte inferior del paño } 1 / 2 \text { al interior del lienzo este } \\
\text { (excavación) }\end{array}$ & 121123 & 100102 \\
\hline & \multirow[t]{10}{*}{104} & \multirow{10}{*}{$\begin{array}{l}\text { Lienzo de muralla en los } \\
\text { tramos del } 1 \text { al } 3\end{array}$} & 1001 & Zarpa del paño $2 / 3$ en el exterior del lienzo este & & 100 \\
\hline & & & 1002 & $\begin{array}{l}\text { Fábrica de grandes sillares con hiladas de } \\
\text { regularización en la parte inferior del lienzo este al } \\
\text { exterior }\end{array}$ & $\begin{array}{c}107108112 \\
121123124 \\
126136\end{array}$ & 100 \\
\hline & & & 1004 & $\begin{array}{l}\text { Piedras de enjarje en el ángulo de encuentro entre el } \\
\text { paño } 2 / 3 \text { y la torre } 2 \text {, exterior del lienzo este }\end{array}$ & & \\
\hline & & & 1007 & $\begin{array}{l}\text { Fábrica de sillarejo con hiladas de regularización en } \\
\text { la parte superior del paño } 2 / 3 \text { y en la torre } 3 \text {, al } \\
\text { exterior del lienzo este }\end{array}$ & 112126 & \\
\hline & & & 1010 & $\begin{array}{l}\text { Jambas, salmeres y su fábrica en el lado externo de } \\
\text { la puerta principal }\end{array}$ & 109126134 & 100 \\
\hline & & & 1016 & $\begin{array}{l}\text { Estructura saliente de la planta de la torre } 3 \text { lado } \\
\text { norte }\end{array}$ & & 100 \\
\hline & & & 1203 & $\begin{array}{l}\text { Muro de mampostería con hiladas de regularización } \\
\text { paños } 1 / 2,2 / 3 \text { y torre } 3 \text {, al interior del lienzo este }\end{array}$ & $\begin{array}{ccc}108 & 112 & 114 \\
116 & 117 & 119 \\
120 & 121 & 124 \\
126 & 127 & 129 \\
130 & 132\end{array}$ & \\
\hline & & & 1222 & $\begin{array}{l}\text { Parte inferior del paño } 2 / 3 \text { al interior del lienzo este } \\
\text { (excavación de estancia 2) }\end{array}$ & & 100 \\
\hline & & & 1223 & $\begin{array}{l}\text { Parte inferior del paño } 2 / 3 \text { al interior del lienzo este } \\
\text { (extremo sur de la estancia } 2 \text { ) }\end{array}$ & & 100 \\
\hline & & & 1229 & $\begin{array}{l}\text { Parte inferior del paño } 1 / 2 \text { y jambas de la puerta } \\
\text { principal al interior del lienzo este }\end{array}$ & $\begin{array}{ll}109 & 124126 \\
127 & 133136 \\
137\end{array}$ & 100 \\
\hline & 105 & $\begin{array}{l}\text { Fábrica de grandes sillares paño } \\
3 / 4, \text { lienzo este }\end{array}$ & 1018 & $\begin{array}{l}\text { Fábrica de grandes sillares y regularización del } \\
\text { paño } 3 / 4 \text { al exterior del lienzo este }\end{array}$ & 107108 & 100 \\
\hline
\end{tabular}


cont.

\begin{tabular}{|c|c|c|c|c|c|c|}
\hline Etapa & Act & Nombre Act & $\mathbf{U E}$ & Nombre UE & Ant a Act & Post a Act \\
\hline \multirow[t]{3}{*}{$1 / 2$} & 106 & $\begin{array}{l}\text { Fábrica base norte de torre } 1 \text { y } \\
\text { lienzo contiguo }\end{array}$ & 1245 & $\begin{array}{l}\text { Fábrica de mampostería regularizada en la base } \\
\text { norte de la torre } 1 \text { y lienzo contiguo }\end{array}$ & 113 & 100 \\
\hline & 111 & $\begin{array}{l}\text { Jamba o cierre portillo extremo } \\
\text { sur paño } 3 / 4 \text {, lienzo este }\end{array}$ & 1023 & $\begin{array}{l}\text { Jamba sur del vano meridional en el paño } 3 / 4 \text { al } \\
\text { exterior del lienzo este }\end{array}$ & 108 & 100 \\
\hline & 115 & $\begin{array}{l}\text { Rellenos bajo reconstrucción } \\
\text { torre } 3\end{array}$ & 1242 & Relleno de tierra en el interior de la torre 3 & 114 & \\
\hline \multirow[t]{7}{*}{2} & 107 & $\begin{array}{l}\text { Fábrica exterior base paño } 3 / 4, \\
\text { lienzo este }\end{array}$ & 1019 & $\begin{array}{l}\text { Fábrica de sillería y cajones de mampostería en el } \\
\text { tramo inferior del paño } 3 / 4 \text { al exterior del lienzo } \\
\text { este }\end{array}$ & 108122 & $\begin{array}{c}100104 \\
105\end{array}$ \\
\hline & \multirow[t]{2}{*}{108} & \multirow{2}{*}{$\begin{array}{l}\text { Fábrica cuerpo superior paño } \\
3 / 4 \text { y posible cegado portillo } \\
\text { extremo sur }\end{array}$} & 1020 & $\begin{array}{l}\text { Obra de mampostería y regularización en la parte } \\
\text { superior del paño } 3 / 4 \text { al exterior del lienzo este }\end{array}$ & 112132 & $\begin{array}{l}104105 \\
107111\end{array}$ \\
\hline & & & 1240 & Paño 3/4 interior del lienzo este & 112129 & 104 \\
\hline & \multirow[t]{2}{*}{109} & \multirow{2}{*}{$\begin{array}{l}\text { Ruina de la puerta de acceso } \\
\text { norte de la muralla }\end{array}$} & 1011 & Ruina de la puerta principal al exterior & 110 & 104 \\
\hline & & & 1230 & Ruina de la puerta principal al interior & 110 & 104 \\
\hline & \multirow[t]{2}{*}{110} & \multirow[t]{2}{*}{$\begin{array}{l}\text { Reconstrucción puerta de } \\
\text { acceso norte de la muralla }\end{array}$} & 1012 & $\begin{array}{l}\text { Arco y muro de mampostería con lajas de } \\
\text { regularización sobre puerta principal al exterior }\end{array}$ & $\begin{array}{c}113124126 \\
134\end{array}$ & 109 \\
\hline & & & 1231 & $\begin{array}{l}\text { Reparación del arco de acceso y muro sobre el } \\
\text { mismo al interior de la puerta principal }\end{array}$ & 112124126 & 109 \\
\hline \multirow[t]{2}{*}{3} & \multirow[t]{2}{*}{116} & \multirow[t]{2}{*}{ Estancias interiores muralla } & 1211 & $\begin{array}{l}\text { Muro de cierre oeste de las estancias, muro norte de } \\
\text { la primera estancia y sur de la segunda, realizados } \\
\text { con hiladas de mampostería y regularizaciones a } \\
\text { sardinel }\end{array}$ & $\begin{array}{lll}117 & 118 & 120 \\
121 & 127 & 128 \\
129 & 131 & 132\end{array}$ & 104 \\
\hline & & & 1220 & Muro de separación entre las estancias 1 y 2 & 121 & 104 \\
\hline \multirow[t]{9}{*}{4} & \multirow[t]{3}{*}{117} & \multirow[t]{3}{*}{ Huecos forjado estancia norte } & 1205 & $\begin{array}{l}\text { Fila de huecos de solado abiertos en } 1203 \text { (primera } \\
\text { estancia, interior lienzo este) }\end{array}$ & & 104 \\
\hline & & & 1212 & $\begin{array}{l}\text { Fila de huecos de solado abiertos en UE } 1211 \\
\text { (muro de cierre oeste) }\end{array}$ & & 116 \\
\hline & & & 1213 & $\begin{array}{l}\text { Hueco abierto junto a la puerta en UE } 1211 \text { (muro } \\
\text { de cierre oeste) }\end{array}$ & & 116 \\
\hline & 118 & Huecos muro oeste estancia sur & 1224 & $\begin{array}{l}\text { Fila de huecos de solado abiertos en UE } 1211 \\
\text { (estancia 2) }\end{array}$ & & 116 \\
\hline & 119 & Huecos muro esta estancia sur & 1221 & $\begin{array}{l}\text { Fila de huecos de solado abiertos en UE } 1203 \\
\text { (estancia 2) }\end{array}$ & & 104 \\
\hline & \multirow[t]{3}{*}{120} & \multirow[t]{3}{*}{$\begin{array}{l}\text { Huecos en muros extremo } \\
\text { meridional estancia sur }\end{array}$} & 1225 & $\begin{array}{l}\text { Huecos abiertos en UE } 1203 \text { (extremo sur de la } \\
\text { estancia 2) }\end{array}$ & & 104 \\
\hline & & & 1226 & $\begin{array}{l}\text { Hueco abierto en UE } 1211 \text { (muro oeste de la } \\
\text { estancia 2, lado sur de la puerta) }\end{array}$ & & 116 \\
\hline & & & 1227 & $\begin{array}{l}\text { Hueco abierto en UE } 1211 \text { (muro sur de la estancia } \\
\text { 2) }\end{array}$ & & 116 \\
\hline & 131 & Hueco para posible soporte & 1214 & $\begin{array}{l}\text { Hueco abierto junto a la puerta en UE1211 (muro } \\
\text { de cierre oeste) }\end{array}$ & & 116 \\
\hline
\end{tabular}


cont.

\begin{tabular}{|c|c|c|c|c|c|c|}
\hline Etapa & Act & Nombre Act & UE & Nombre UE & Ant a Act & Post a Act \\
\hline \multirow[t]{6}{*}{5} & \multirow[t]{4}{*}{121} & \multirow[t]{4}{*}{ Edículos ganaderos } & 1026 & Desagüe superior en lienzo $2 / 3$ al exterior & & 104 \\
\hline & & & 1208 & Desagüe abierto en UE 1203 & & 104 \\
\hline & & & 1209 & $\begin{array}{l}\text { Enfoscado en paños } 1 / 2 \text { y } 2 / 3 \text { interior lienzo este, } \\
\text { y muros de la cochiquera en las dos estancias }\end{array}$ & 123125132 & $\begin{array}{c}103104 \\
116\end{array}$ \\
\hline & & & 1218 & $\begin{array}{l}\text { Roza y huecos para marco de puerta en la primera } \\
\text { estancia }\end{array}$ & & \\
\hline & 122 & Cegado portillo norte paño $2 / 3$ & 1021 & Sellado del vano del muro UE 1019 & 135 & 107 \\
\hline & 128 & Ruina estancias interiores & 1219 & Ruinas muros UE 1211 & & 116 \\
\hline \multirow[t]{10}{*}{6} & \multirow[t]{2}{*}{112} & \multirow[t]{2}{*}{ Ruina zona superior muralla } & 1017 & Ruina de las UE 1007 (exterior) y 1203 (interior) & 114 & 104108 \\
\hline & & & 1232 & $\begin{array}{l}\text { Corte horizontal de la parte superior de UE } 1231 \text { al } \\
\text { interior }\end{array}$ & 113 & 110 \\
\hline & \multirow[t]{2}{*}{113} & \multirow[t]{2}{*}{$\begin{array}{l}\text { Reconstrucción torre } 1 \text { y } \\
\text { adarves paño } 1 / 2\end{array}$} & 1013 & $\begin{array}{l}\text { Tramo de muro saliente sobre la fachada de la } \\
\text { puerta principal y torre } 1 \text {, exterior }\end{array}$ & 126 & $\begin{array}{c}100106 \\
110\end{array}$ \\
\hline & & & 1233 & $\begin{array}{l}\text { Recrecimiento de la parte superior del paño } 1 / 2 \\
\text { sobre la puerta principal al interior }\end{array}$ & 124126 & 112 \\
\hline & \multirow[t]{3}{*}{114} & \multirow[t]{3}{*}{ Reconstrucción torre 3} & 1008 & $\begin{array}{l}\text { Fábrica de mampostería en la parte superior del } \\
\text { extremo sur del paño } 2 / 3 \text { y torre } 3 \text {, al exterior del } \\
\text { lienzo este }\end{array}$ & 112 & \\
\hline & & & 1239 & Parte superior de la torre 3 al interior del lienzo este & 112 & \\
\hline & & & 1241 & Forro interior de la torre 3 & 104115 & \\
\hline & \multirow[t]{2}{*}{123} & \multirow[t]{2}{*}{ Aliviadero cisterna } & 1025 & Desagüe inferior en lienzo $2 / 3$ al exterior & & 104 \\
\hline & & & 1210 & Estructura de mampostería y losas de la atarjea & & 103121 \\
\hline & 133 & $\begin{array}{l}\text { Cierre de hierro en puerta de } \\
\text { acceso principal }\end{array}$ & 1236 & $\begin{array}{l}\text { Parches de cemento al interior de las jambas de la } \\
\text { puerta principal }\end{array}$ & & 104 \\
\hline
\end{tabular}


cont.

\begin{tabular}{|c|c|c|c|c|c|c|}
\hline Etapa & Act & Nombre Act & $\mathbf{U E}$ & Nombre UE & Ant a Act & Post a Act \\
\hline \multirow[t]{21}{*}{7} & \multirow[t]{2}{*}{124} & \multirow[t]{2}{*}{$\begin{array}{l}\text { Ruina anterior a la } \\
\text { reconstrucción de la muralla }\end{array}$} & 1009 & $\begin{array}{l}\text { Ruina de UE } 1002 \text { en el paño } 1 / 2 \text { y torre } 3 \text {, exterior } \\
\text { lienzo este }\end{array}$ & 126 & 104110 \\
\hline & & & 1234 & Ruina de la parte superior del lienzo $1 / 2$ & 126 & $\begin{array}{c}104110 \\
113\end{array}$ \\
\hline & 125 & Ruina edículos ganaderos & 1217 & $\begin{array}{l}\text { Ruina de los muros de la cochiquera en las } \\
\text { estancias } 1 \text { y } 2\end{array}$ & & 121 \\
\hline & \multirow[t]{4}{*}{126} & \multirow[t]{4}{*}{ Reparaciones contemporáneas } & 1003 & $\begin{array}{l}\text { Parte superior del paño } 1 / 2 \text { y de la torre } 2 \text { al } \\
\text { exterior del lienzo este }\end{array}$ & & $\begin{array}{l}104110 \\
113124\end{array}$ \\
\hline & & & 1005 & $\begin{array}{l}\text { Fábrica de mampostería sobre el adarve en la parte } \\
\text { superior sur de la torre } 2\end{array}$ & & 104 \\
\hline & & & 1006 & $\begin{array}{l}\text { Dos hiladas superiores en el encuentro entre el paño } \\
2 / 3 \text { y la torre } 2 \text {, cara exterior lienzo este }\end{array}$ & & 104 \\
\hline & & & 1204 & $\begin{array}{l}\text { Parte superior del paño } 1 / 2 \text { al interior del lienzo } \\
\text { este }\end{array}$ & 127 & $\begin{array}{l}104110 \\
113124\end{array}$ \\
\hline & \multirow[t]{2}{*}{127} & \multirow[t]{2}{*}{$\begin{array}{l}\text { Caseta control de acceso al } \\
\text { castillo }\end{array}$} & 1215 & $\begin{array}{l}\text { Hueco abierto en el centro de UE } 1211 \text { (muro de } \\
\text { cierre oeste) }\end{array}$ & & 116 \\
\hline & & & 1228 & Caseta control de acceso al castillo & & $\begin{array}{c}104116 \\
126\end{array}$ \\
\hline & 129 & $\begin{array}{l}\text { Última colmatación frente a } \\
\text { cara interior paño } 2 / 3 \text {, lienzo } \\
\text { este }\end{array}$ & 1243 & $\begin{array}{l}\text { Relleno de tierra al interior del lienzo este, paños } \\
2 / 3,3 / 4 \text { y torre } 3\end{array}$ & 130 & $\begin{array}{l}104108 \\
116\end{array}$ \\
\hline & 130 & Escalera de acceso a torre 3 & 1244 & Escalera de acceso a torre 3 & & 104129 \\
\hline & \multirow[t]{4}{*}{132} & \multirow[t]{4}{*}{$\begin{array}{l}\text { Pérdida de material en lienzo } \\
\text { este de la muralla }\end{array}$} & 1024 & $\begin{array}{l}\text { Pérdida de material en el paño } 3 / 4 \text { y torre } 3 \text {, al } \\
\text { exterior del lienzo este }\end{array}$ & & 104108 \\
\hline & & & 1206 & $\begin{array}{l}\text { Hueco bajo abierto en UE } 1203 \text { (primera estancia, } \\
\text { interior lienzo este) }\end{array}$ & & 104 \\
\hline & & & 1207 & $\begin{array}{l}\text { Hueco alto abierto en UE } 1203 \text { (primera estancia, } \\
\text { interior lienzo este) }\end{array}$ & & 104 \\
\hline & & & 1216 & Huecos abiertos en UE 1211 (muro norte) & & 121116 \\
\hline & \multirow[t]{3}{*}{134} & \multirow[t]{3}{*}{ Placas en acceso a monumento } & 1014 & $\begin{array}{l}\text { Agujeros para placa sobre la puerta principal al } \\
\text { exterior }\end{array}$ & & 110 \\
\hline & & & 1015 & $\begin{array}{l}\text { Agujeros para placa en el lado norte de la puerta } \\
\text { principal al exterior }\end{array}$ & & 104 \\
\hline & & & 1235 & $\begin{array}{l}\text { Huecos del lado interno de la puerta principal } \\
\text { jamba sur }\end{array}$ & & 104 \\
\hline & 135 & Rotura sellado portillo & 1022 & Eliminación parcial de UE 1021 & & 122 \\
\hline & 136 & Rotura muro junto a garita & 1237 & Agujero en UE 1229 & 137 & 104 \\
\hline & 137 & Reparación rotura UE 1237 & 1238 & Relleno del agujero UE 1237 & & 104136 \\
\hline
\end{tabular}




\section{Cisterna del Castelo dos Mouros}

\begin{tabular}{|c|c|c|c|c|c|c|}
\hline Etapa & Act & Nombre Act & $\mathbf{U E}$ & Nombre UE & Ant a Act & Post a Act \\
\hline $2 / 5$ & 200 & Cisterna & 1500 & Muros y suelo de sillería de la cisterna & 201203 & \\
\hline \multirow[t]{6}{*}{6} & \multirow[t]{3}{*}{201} & \multirow[t]{3}{*}{$\begin{array}{l}\text { Tímpano testeros y bóveda } \\
\text { cisterna }\end{array}$} & 1501 & Bóveda y arcos fajones de la cisterna & $\begin{array}{l}204205 \\
206\end{array}$ & 200 \\
\hline & & & 1509 & Muro sur con acceso a cisterna & 202203 & 200 \\
\hline & & & 1510 & Muro testero sur de la cisterna (sobre imposta) & & 200 \\
\hline & \multirow[t]{3}{*}{202} & \multirow[t]{3}{*}{ Remate de obra bóveda cisterna } & 1505 & $\begin{array}{l}\text { Parte superior muro de mampostería testero sur de } \\
\text { la cisterna }\end{array}$ & & 201 \\
\hline & & & 1506 & Muro perpendicular al testero sur de la cisterna & & 201 \\
\hline & & & 1508 & Relleno de tierras sobre la bóveda de la cisterna & & \\
\hline \multirow[t]{5}{*}{7} & \multirow[t]{2}{*}{203} & \multirow{2}{*}{$\begin{array}{l}\text { Barandilla y reja en acceso } \\
\text { cisterna }\end{array}$} & 1504 & Barandilla de metal parte superior de la escalera & & 200 \\
\hline & & & 1511 & Puerta de reja y marco de cemento & & 201 \\
\hline & 204 & Forro pozos exteriores cisterna & 1507 & $\begin{array}{l}\text { Forro de mampostería de los pozos de la cisterna al } \\
\text { exterior }\end{array}$ & & 201 \\
\hline & 205 & $\begin{array}{l}\text { Ampliación respiradero ángulo } \\
\text { sureste cisterna }\end{array}$ & 1503 & $\begin{array}{l}\text { Rotura para introducir tubería de PVC en la esquina } \\
\text { sureste de la bóveda }\end{array}$ & & 201 \\
\hline & 206 & Rotura base cisterna & 1502 & Rotura de la base del pozo meridional de la cisterna & & 201 \\
\hline
\end{tabular}

\section{Iglesia de São Pedro do Canaferrin}

\begin{tabular}{|c|c|c|c|c|c|c|}
\hline Etapa & Act & Nombre Act & $\mathbf{U E}$ & Nombre UE & Ant a Act & Post a Act \\
\hline \multirow[t]{3}{*}{1} & \multirow[t]{3}{*}{300} & \multirow[t]{3}{*}{$\begin{array}{l}\text { Ábside y muro sur nave iglesia } \\
\text { originaria }\end{array}$} & 1600 & Ábside rectangular de la iglesia & $\begin{array}{c}301302 \\
304305 \\
306307 \\
308313 \\
315316 \\
317318 \\
326\end{array}$ & 100 \\
\hline & & & 1614 & Muro y puerta sur de la nave & $\begin{array}{l}307308 \\
310311 \\
314326\end{array}$ & 100 \\
\hline & & & 1618 & Parte inferior del testero oeste de la nave, lado sur & $\begin{array}{l}304305 \\
307309 \\
310326\end{array}$ & 100 \\
\hline $1 / 2$ & 301 & Encalado del ábside & 1610 & Restos de encalado del interior del ábside & $\begin{array}{c}306316 \\
318\end{array}$ & 300 \\
\hline \multirow[t]{2}{*}{$2 \mathrm{a}$} & 302 & Ruina del muro norte de la nave & 1628 & Ruina del muro norte de la nave & 303305 & 300 \\
\hline & 303 & Nuevo muro norte del aula & 1619 & $\begin{array}{l}\text { Parte inferior del testero oeste de la nave, sector } \\
\text { norte, y muro norte }\end{array}$ & $\begin{array}{l}304305 \\
310322 \\
323326\end{array}$ & 302 \\
\hline
\end{tabular}


cont.

\begin{tabular}{|c|c|c|c|c|c|c|}
\hline Etapa & Act & Nombre Act & $\mathbf{U E}$ & Nombre UE & Ant a Act & Post a Act \\
\hline \multirow[t]{5}{*}{$2 b$} & \multirow[t]{3}{*}{304} & \multirow{3}{*}{$\begin{array}{l}\text { Ruina de los muros norte y oeste } \\
\text { de la nave }\end{array}$} & 1620 & Ruina del testero oeste de la nave mitad sur & 305 & 300 \\
\hline & & & 1623 & Ruina del testero oeste de la nave, mitad norte & 305 & 303 \\
\hline & & & 1624 & $\begin{array}{l}\text { Solución de continuidad horizontal en el muro norte } \\
\text { de la nave }\end{array}$ & 305 & 300303 \\
\hline & \multirow[t]{2}{*}{305} & \multirow[t]{2}{*}{$\begin{array}{l}\text { Nuevos muros norte y oeste del } \\
\text { aula }\end{array}$} & 1601 & $\begin{array}{l}\text { Testero sobre el trasdós de la bóveda del ábside } \\
\text { (este, sur y norte) }\end{array}$ & 312 & 300 \\
\hline & & & 1621 & $\begin{array}{l}\text { Reconstrucción del testero oeste y muro norte de la } \\
\text { nave }\end{array}$ & $\begin{array}{l}307312 \\
319320 \\
321323\end{array}$ & $\begin{array}{l}300302 \\
303304\end{array}$ \\
\hline \multirow[t]{8}{*}{$2 \mathrm{c}$} & 306 & Pinturas en la bóveda del ábside & 1605 & Pinturas en el interior del ábside & & 300301 \\
\hline & \multirow[t]{2}{*}{315} & \multirow[t]{2}{*}{$\begin{array}{l}\text { Puerta de cierre de la } \\
\text { embocadura del ábside }\end{array}$} & 1606 & $\begin{array}{l}\text { Pareja de huecos cuadrados enfrentados en las } \\
\text { jambas interiores del arco de embocadura del ábside }\end{array}$ & & 300 \\
\hline & & & 1607 & $\begin{array}{l}\text { Pareja de huecos enfrentados tallados en el zócalo } \\
\text { del arco de embocadura del ábside }\end{array}$ & & 300 \\
\hline & 317 & Reducción ventana del ábside & 1609 & $\begin{array}{l}\text { Construcción de un umbral más alto en la ventana } \\
\text { del ábside }\end{array}$ & 325 & 300 \\
\hline & 318 & $\begin{array}{l}\text { Rotura de la imposta sur de la } \\
\text { embocadura del ábside }\end{array}$ & 1611 & $\begin{array}{l}\text { Corte en imposta sur del arco de embocadura del } \\
\text { ábside }\end{array}$ & & 300301 \\
\hline & 319 & $\begin{array}{l}\text { Muro adosado a la esquina } \\
\text { noroeste de la nave }\end{array}$ & 1625 & $\begin{array}{l}\text { Corte en el encadenado de la esquina noroeste de la } \\
\text { nave }\end{array}$ & & 305 \\
\hline & 320 & $\begin{array}{l}\text { Gorronera en puerta norte de la } \\
\text { nave }\end{array}$ & 1629 & $\begin{array}{l}\text { Gorronera del dintel interior de la puerta norte de la } \\
\text { nave }\end{array}$ & & 305 \\
\hline & 321 & $\begin{array}{l}\text { Pareja de gorroneras en la puerta } \\
\text { norte de la nave }\end{array}$ & 1630 & $\begin{array}{l}\text { Pareja de gorroneras del dintel exterior de la puerta } \\
\text { norte de la nave }\end{array}$ & & 305 \\
\hline \multirow[t]{12}{*}{6} & \multirow[t]{2}{*}{307} & \multirow[t]{2}{*}{ Abandono y ruina de la iglesia } & 1616 & Ruina de las esquinas meridionales de la nave & 308 & 300 \\
\hline & & & 1622 & Pérdida o robo de la puerta oeste de la nave & 309310 & 305 \\
\hline & \multirow[t]{2}{*}{308} & \multirow{2}{*}{$\begin{array}{l}\text { Reconstrucción de las esquinas } \\
\text { del muro sur }\end{array}$} & 1604 & Restauración de la esquina sureste de la nave & 326 & 300307 \\
\hline & & & 1615 & Reparación de la esquina exterior suroeste de la nave & 309 & 307 \\
\hline & 309 & Jardineras & 1626 & Jardinera en el testero oeste de la nave & & $\begin{array}{l}300307 \\
308310\end{array}$ \\
\hline & \multirow[t]{2}{*}{310} & \multirow[t]{2}{*}{ Escaleras muro oeste } & 1613 & Escalera de acceso a la puerta sur & 311326 & 300 \\
\hline & & & 1627 & Escalera oeste & 309326 & $\begin{array}{c}300303 \\
307\end{array}$ \\
\hline & 313 & $\begin{array}{l}\text { Muro adosado a la esquina } \\
\text { sureste del ábside }\end{array}$ & 1602 & Huella de muro perpendicular al testero del ábside & & 300 \\
\hline & 316 & Reja en la embocadura del ábside & 1608 & $\begin{array}{l}\text { Huecos de anclaje de reja en el arco de embocadura } \\
\text { del ábside }\end{array}$ & & 300301 \\
\hline & 322 & $\begin{array}{l}\text { Pérdida del umbral de la puerta } \\
\text { norte de la nave }\end{array}$ & 1631 & Pérdida del umbral de la puerta norte de la nave & & 303 \\
\hline & 323 & $\begin{array}{l}\text { Pérdida de material en el muro } \\
\text { norte de la nave }\end{array}$ & 1632 & Agujeros en el interior del muro norte de la nave & 324 & 305303 \\
\hline & 325 & $\begin{array}{l}\text { Desmonte de la reducción de la } \\
\text { ventana del ábside }\end{array}$ & 1634 & Desmonte del umbral UE 1609 & & 317 \\
\hline
\end{tabular}


cont.

\begin{tabular}{|c|c|c|c|c|c|c|}
\hline Etapa & Act & Nombre Act & UE & Nombre UE & Ant a Act & Post a Act \\
\hline \multirow[t]{5}{*}{7} & 311 & Restauración de la puerta sur & 1612 & $\begin{array}{l}\text { Reposición de piedras y reconstrucción del tímpano } \\
\text { de la puerta sur }\end{array}$ & & 300310 \\
\hline & 312 & $\begin{array}{l}\text { Encapotado de cemento de la } \\
\text { bóveda del ábside }\end{array}$ & 1617 & Encapotado de cemento de la bóveda del ábside & & 305 \\
\hline & 314 & $\begin{array}{l}\text { Relleno agujero en el muro sur } \\
\text { del ábside }\end{array}$ & 1603 & $\begin{array}{l}\text { Reparación con mampostería de la cara sur del } \\
\text { ábside }\end{array}$ & & 300 \\
\hline & 324 & $\begin{array}{l}\text { Relleno de piedras en agujero del } \\
\text { muro norte de la nave }\end{array}$ & 1633 & $\begin{array}{l}\text { Reparación de agujero en el interior del muro norte } \\
\text { de la nave }\end{array}$ & & 323 \\
\hline & 326 & Suelo actual de la nave & 1635 & Suelo actual de la nave de la iglesia & & $\begin{array}{l}300303 \\
308310\end{array}$ \\
\hline
\end{tabular}

\section{BIBLIOGRAFÍA}

Anónimo 1863: Novo Guia do Viajante em Lisboa e seus arredores. J. J. Bordado, Lisboa.

Alexander, J. E. [1803-1885] 2003: Um esboço de Portugal durante a Guerra Civil de 1834. Livros Horizonte, Lisboa.

Bessac, J. C. 1986: L'outillage traditionnel du tailleur de pierre. CNRS editions, Paris.

Cachado, J. 2009: Vistas de Cintra em desenhos de Clémentine Brélaz. 1840. Parques da Sintra - Monte da Lua, S. A., Sintra.

Campos, C. de 1965: Arqueologia Árabe em Portugal. Edição do Autor, Lisboa.

Cardim, J. 1998: Sintra Património da Humanidade. Câmara municipal, Sintra

Cardoso, J. L. 1997-1998: "O Povoado do Bronze Final do Castelo dos Mouros (Sintra)", Estudos Arqueológicos de Oeiras, 7, pp. 169-187.

Cardoso, J. L. y Sousa, M. J. de 2014: "O Bronze Final na Serra de Sintra", Estudos Arqueológicos de Oeiras, 21, pp. 361-374.

Castro, Abade A. D. de [1804-1876] 1843: Investigação ao castello situado na serra de Cintra. Typographia de A. J. C. da Cruz, Lisboa.

Coelho, C. 2000: "A ocupação islâmica do Castelo dos Mouros (Sintra): interpretação comparada”, Revista Portuguesa de Arqueologia, 3, 1200, pp. 207-225.

Coelho, C. 2002: “O Castelo dos Mouros (Sintra)", en I. C. F. Fernandes (coord.), Mil anos de Fortificações na Península Ibérica e no Magreb (500-1500): Actas do Simpósio Internacional sobre Castelos, pp. 389-395. Edições Colibri / Câmara Municipal de Palmela, Lisboa.

Coelho, C. 2012: "A cerâmica verde e manganés do Castelo de Sintra", Arqueologia Medieval, 12, pp. 91-107.

Costa, F. 1980: O Paço Real de Sintra: Novos subsídios para a sua história. Câmara Municipal, Sintra.

Esquieu, Y. y Hartmann-Virnich, A. 2007 : "Les signes lapidaires dans la construction médiévale: études de cas et problèmes de méthode", Bulletin Monumental, 165 (4), pp. 331- 358.

Fernandes, A. R., Sousa, M. J. de y Carvalho, A. F. 2016: "Cerâmica simbólica" neolótica do Castelo dos Mouros", Revista Portuguesa de Arqueologia, 19, pp. 33-40.

Gouveia, M. de y Sousa, M. J. de 2017: "Moedas da primeira dinastia provenientes do Castelo dos Mouros (Sintra): notícia preliminar das escavações arqueológicas de 2009-2011", Revista M, 0, pp. 73-79.

Pavón, B. 1993: Ciudades y fortalezas lusomusulmanas. Crónicas de viajes por el sur de Portugal. Instituto de Cooperación con el Mundo Árabe, Madrid.
Pereira, F. A. 1975: Sintra do Pretérito. Câmara Municipal, Sintra.

Pereira, P. 1995: "O revivalismo: A arquitectura do desejo", en P. Pereira (dir.): História da Arte Portuguesa, vol. 3, pp. 353-367. Círculo de Leitores, Lisboa.

Real, M. L. 1982-1983: "Perspectivas sobre a flora românica da "Escola" Lisbonense. A propósito de dois capitéis desconhecidos de Sintra, no Museu do Carmo", Sintria, I-II, pp. 529-560.

Rodil, J. y Carvalho, S. L. de 1995: Sintra: As Pedras e o Tempo. Ministério da Educação, Sintra.

Rodrigues, J. 1995: "O mundo românico (séculos XI-XIII)”, en P. Pereira (dir.), História da Arte Portuguesa, vol. 1, pp. 257-262. Círculo de Leitores, Lisboa.

Saldanha, A. N. 1988: "A capela de S. Pedro de Canaferrim, em Sintra. Contributos para o estudo de um monumento esquecido", Aedificiorum, I, Junio, pp. 35-39.

Serrão, V. 1980: "Um ignorado templo pré-românico: A capela de S. Pedro do Castelo dos Mouros", Jornal de Sintra, abril-mayo, pp. 2382 - 2384.

Serrão, V. 1989: Sintra. Presença, Lisboa.

Simões, T. 1999: O sitio neolítico de São Pedro de Canaferrim, Sintra: contribuiçoes para o estudio da neolitizaçao da Península de Lisboa, Trabalhos de Arqueología, 12. Instituto Português de Arqueologia, Lisboa.

Sousa, M. J. de 2013: “À Conquista do Castelo". Campo de investigação arqueológica do Castelo dos Mouros I Sintra - primeiros resultados”, en I. C. F. Fernandes (coord.), Fortificações e Território na Penínsua Ibérica e no Magreb (séculos VI a XVI), vol. II, pp. 813-819. Edições Colibri / Câmara Municipal de Palmela, Lisboa.

Sousa, M. J. de 2015: "Uma habitação do século XI/XII sob a muralha do Castelo dos Mouros de Sintra - Evidências arqueológicas de um contexto doméstico", en M. J. Gonçalves y S. Gómez Martínez (coords.), Actas do $X$ Congresso Internacional a Cerâmica Medieval no Mediterrâneo. Silves, 22 a 27 Outubro 2012, pp. 262-265, Silves.

Sousa, M. J. de y Carvalho, A. F. 2015: “Campo de investigação arqueológica do Castelo dos Mouros, Sintra (Portugal): achado de um vaso neolítico inteiro", en V. S. Gonçalves, M. Diniz y A. C. Sousa (eds.), V Congreso do Neolitico Peninsular, pp. 280-283. UNIARQ, Lisboa.

Torres, C. y Macías, S. 1995: “A arte islâmica no Ocidente Andaluz”, en P. Pereira (dir.), História da Arte Portuguesa, vol. 1, pp. 153-177. Círculo de Leitores, Lisboa.

Utrero, M. A. 2006: Iglesias tardoantiguas y altomedievales en la península Ibérica. Análisis arqueológico y sistemas de abovedamiento, Anejos de Archivo Español de Arqueología XL. Consejo Superior de Investigaciones Científicas, Madrid. 